Monetary Spillovers and Real Exchange Rate Misalignments in Emerging Markets

Krittika Banerjee and Ashima Goyal

Indira Gandhi Institute of Development Research, Mumbai September 2020 


\title{
Monetary Spillovers and Real Exchange Rate Misalignments in Emerging Markets
}

\author{
Krittika Banerjee and Ashima Goyal
}

Email(corresponding author): ashima@igidr.ac.in

\begin{abstract}
After the adoption of unconventional monetary policies (UMP) in advanced economies (AEs) there were many studies of monetary spillovers to asset prices in emerging market economies (EMEs) but the extent of contribution of EMEs and AEs respectively in real exchange rate (RER) misalignments has not been addressed. Using fixed effects, pooled mean group and common correlated effects we address the gap in a cross-country panel set-up with country specific controls. Multi-way clustering is used to ensure robust statistical inferences. Robust evidence is found for significant monetary spillovers over 1998-2017 in the form of RER overvaluation of EMEs against AEs, especially through the portfolio rebalancing channel. EME RER against US saw significantly more overvaluation in UMP years indicating greater role of US in monetary spillovers. However, in the long run monetary neutrality holds. EMEs did pursue mercantilist and precautionary policies that undervalued their RERs. Precautionary undervaluation is more evident with bilateral EME US RER. Export diversification reduces EME mercantilist motives against US. That AE monetary policy significantly appreciates EME RER should be kept in mind for future policy cooperation between EMEs and AEs.
\end{abstract}

Keywords: Unconventional monetary policies; monetary spillovers; mercantilist; precautionary, pooled mean group; common correlated effects; cluster robust.

JEL Code: E4, E5, F3, F42 


\section{Monetary Spillovers and Real Exchange Rate Misalignments in Emerging Markets}

\section{Introduction}

In the years leading up to the global financial crisis (GFC), mercantilist and precautionary objectives ${ }^{1}$ in emerging market economies (EMEs) were held responsible for global current account imbalances with advanced economies (AEs) (Bernanke, 2005). There was, however, a counter-perspective that lax regulatory regimes and over-lending in AEs were also responsible for the GFC (Wang, 2012). Post GFC, in order to address severe systemic liquidity shortages AEs embarked on a huge liquidity injection through unconventional channels ${ }^{2}$ like purchases of long term sovereign bonds or mortgage backed securities, also known as unconventional monetary policy (UMP). Central Banks such as the Federal Reserve (Fed), the European Central Bank (ECB), and to some extent, Bank of Japan (BoJ) and Bank of England adopted a variety of other non-standard measures ${ }^{3}$ like signalling or forward guidance, longerterm refinancing operations, emergency lending etc. (Cecchetti and Disyatat, 2010).

Although these measures alleviated the liquidity situation, the 'competitive easing' (Rajan, 2015) was a threat to independent monetary policy in developing or periphery countries as the QE money started to flow to these countries. Several papers like Rey (2013), Nier et al. (2014), Rajan (2015), Passari and Rey (2015), Anaya et al. (2017) raised concerns about dwindling choices for EMEs in the face of a 'liquidity tsunami'. This turned the debate to monetary spillovers and costs borne by EMEs. For example, cumulative asset purchases by the Fed, in three distinct phases over 2008-13, reached almost 90 billion US dollars in 2013, after which the exit from easing mode started ("tapering"). The resulting fall in long term bond yields in the AEs, made investors rebalance their portfolios towards EME assets in search of better returns. Capital inflows to EMEs surged during the UMP period (Chen et al., 2014; Lin et al., 2017). Alongside fall in bond yields, EME currencies were also impacted. Exchange rates in recipient countries saw appreciation during the UMP phase, while depreciation was common with news of tapering (Aizenman et al., 2014; Tillmann, 2016). Thus, it became evident that foreign policy spillovers as well as domestic policies were increasingly influencing EME exchange rates. Alpanda and Kabaca (2020) show this volatility could deteriorate EME trade balances, despite the output expansion through fall in long term interest rates.

\footnotetext{
${ }^{1}$ Aizenman and Lee (2005) show two major motives affecting exchange rates, one, the mercantilist motive that suppresses RER artificially to gain on exports, two, the precautionary motive which hoards reserves to insure against volatile capital flows and sudden stops. Both result in RER undervaluation.

${ }^{2}$ AEs had little scope to change the policy interest rate which was near zero.

${ }^{3}$ Together known as quantitative easing (QE).
} 
In this context, existing empirical studies study EME nominal exchange rates, but do not address EME real exchange rates (RER) ${ }^{4}$ and their misalignments, which are more crucial for net exports and growth. RER depends on nominal exchange rate and cross-country relative price, as well as EME structural factors. Although in the presence of arbitrage, purchasing power parity (PPP) should define the equilibrium RER, it has been well established in the literature that the RER deviates from PPP (Triki and Maktouf, 2015) because of persistent structural or behavioural features of EMEs. Hence, equilibrium RERs are usually estimated accounting for these factors. Misalignments from such equilibrium can occur mainly due to distortionary external/internal policies.

With the financial liberalisation that occurred in the 1990s, which led to increased capital flows, EMEs increasingly adopted market intervention to serve domestic purposes like checking currency appreciation or reserve accumulation (Nayak and Baig, 2019). This served mercantilist/precautionary interests but may misalign the RER from equilibrium defined by domestic fundamentals. But as argued above, AE monetary policy can also misalign EME RER. Existing studies do not assess these aspects. We address this research gap by studying the impact of AE monetary policy on RER misalignments. Since AE monetary policy is distinguishable into conventional (CMP) and unconventional (UMP) phases, we also test whether CMP has different effects from UMP. The impact of CMP also helps to understand how AE monetary policy in normal years affects EMEs.

The relative contribution of EME and AE policies to RER misalignments also remains to be addressed to the best of our knowledge. This paper addresses it by testing the relative impact of domestic mercantilist/precautionary objectives against foreign monetary policy spillovers on misalignments from behavioural equilibrium RER for a set of systemic large EMEs, subject to controls for country economic heterogeneity. EMEs that are largest in terms of both absolute and per capita incomes ${ }^{5}$, are selected because of their size and importance in global trade and finance.

The impact of UMP for EMEs has been studied mainly on asset prices and capital flows. Aizenman et al. (2014), Dedola et al. (2017), MacDonald (2017) found appreciatory pressure on currencies in EMEs, while Bowman et al. (2014), Tillmann (2016), MacDonald (2017), Dedola et al. (2017) found downward pressure on Government bond yields. Studies like Chen et al. (2014), Lim et al. (2014), Ahmed and Zlate (2014) found increased capital flows to EMEs. Impact on stock markets in EMEs have also been explored (Lin et al., 2017; Chebbi, 2019). Another group of papers focussed on the impact of UMP in the 'tapering' phase, and consequent doldrums in the EMEs (Aizenman et al.,2014; Mishra et al., 2014;

\footnotetext{
${ }^{4}$ It is the relative price between foreign and domestic economies when expressed in same currency. Here, $\mathrm{RER}=\mathrm{SP} * / \mathrm{P}$ where $\mathrm{S}$ is the nominal exchange rate, $\mathrm{P} *$ and $\mathrm{P}$ foreign and domestic prices respectively.

${ }^{5}$ They accounted for around 30 percent of world GDP in 2018 and attained average per capita income around 1.5 times the same in developing nations.
} 
Papadamou et al., 2019), with reverse depreciation and capital outflows. Existing studies indicate that portfolio rebalancing of investors was the largest transmission channel of UMP (Papadamou et al., 2020).

The normalised ${ }^{6}$ balance sheets of Central Banks in the three most discussed UMP programs by US, Euro Area and Japan, plotted in Figure 1, show the extent of the 'competitive easing'. While the QE1 took the balance sheet of the Fed from 0.89 in 2007 to 2.91 trillion USD in 2012, ECB matched by expanding its balance sheet to 3.31 trillion Euros in 2012 from 1.72 in 2007. The Fed announcements were often cue to new ECB announcements (Dedola et al., 2017 has a detailed analysis of the relative balance sheet between Euro area and US). The ECB's balance sheet expansion slumped after 2012. Starting 2015, it expanded again with the Public Sector Purchase Programme. BoJ was late in expanding its balance sheet, but rapid expansion from 2013 onwards led to levels considerably higher than Fed and ECB by 2017. While ECB and BoJ were in easing mode till 2017, Fed started tightening its monetary policy after 2015. In comparison, the average normalised balance sheet of some key EMEs (Figure 1) remained far below that of the AEs, particularly after the GFC. The trend is almost the same for India.

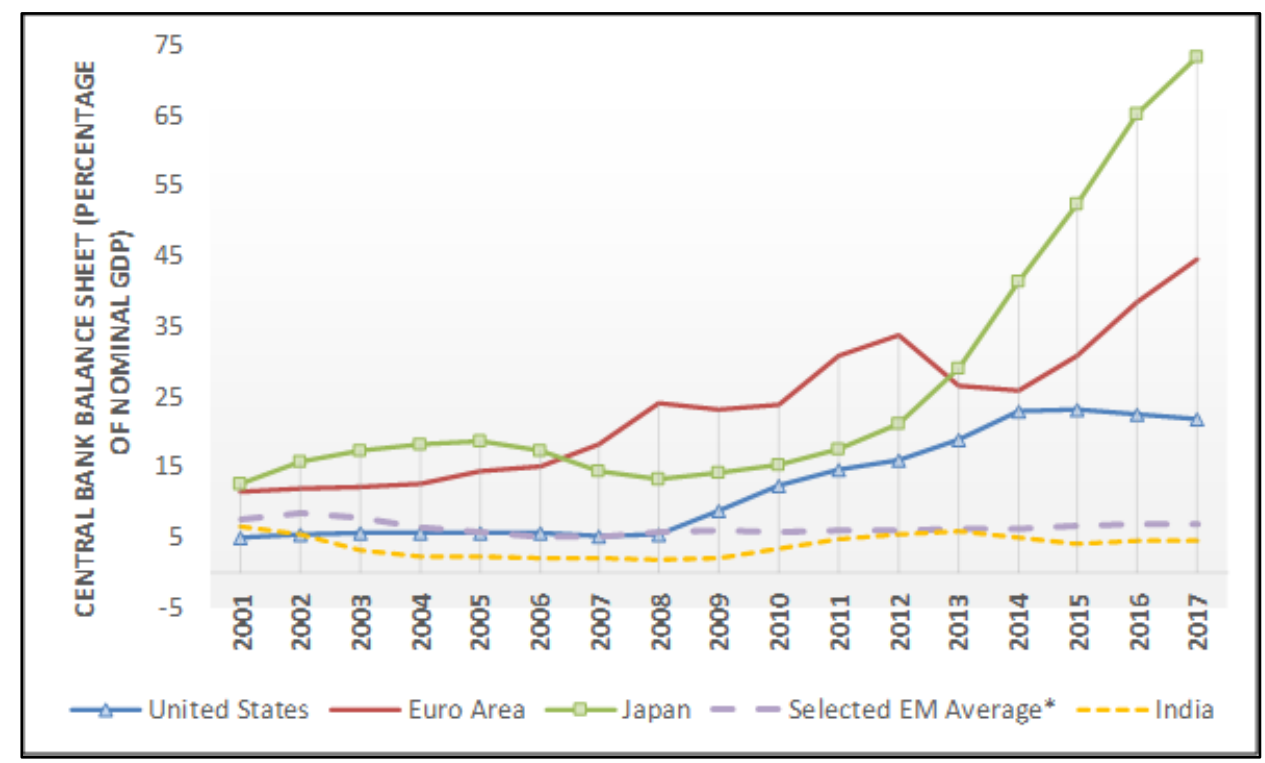

Fig. 1 Central Bank Balance Sheet Movements

Note: Selected emerging markets are Brazil, China, India, Indonesia, Mexico, Russia, Thailand and Turkey. Source: IMF IFS Monetary and Financial Accounts, World Bank Global Financial Development database

AE expansionary policy weakens its own currency. The other side of the coin is a matching upward pressure on EME currency. EMEs may look to reduce the pressure through reserve accumulation to achieve domestic objectives like exports or suppressing volatility. In Figure 2 below, we plot the foreign

\footnotetext{
${ }^{6}$ Normalisation has been done with respect to nominal GDP keeping in mind the currency differences as well as the variations in country sizes.
} 
exchange reserves-to-GDP ratio in eight major EMEs analysed against weighted broad money of US, UK and Japan. Almost the entire 2000s was a period of reserve accumulation for these EMEs, except Indonesia which registered a fall in reserves from as early as 2000. Turkey shows a volatile reserves ratio. China, Thailand and Russia show the highest rates of reserve accumulation. While peak year reserves averaged around 18 percent for other EMEs, China and Thailand respectively reached 47 and 49 percent of GDP. Russia accumulated 35 percent in the peak year. A co-movement can be seen in the two series for most EMEs indicating correlation between reserves and money supply in the AEs. In the case of China, India and Russia, the post-crisis period shows some decoupling between the two variables. Thus, an EME cannot act independently but has to move in response to AE policy stances, especially through intervention to maintain internal and external balances.

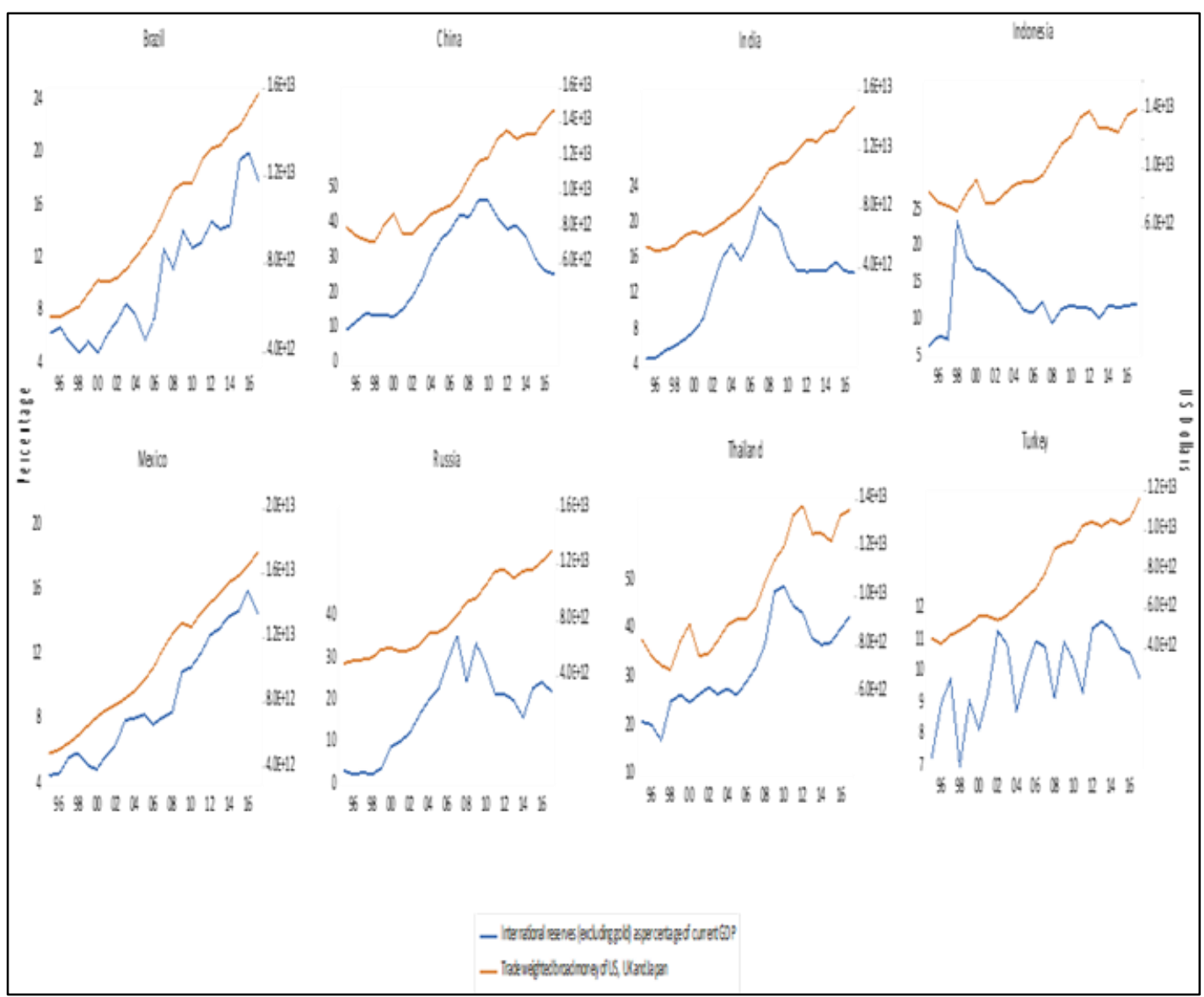

Fig 2. Foreign exchange reserves to GDP ratio and AE money supply Source: World Development Indicators

The literature has an abundance of high-frequency data analysis, mostly event studies (e.g. Chen et al., 2014, Tillmann, 2016) around the time of QE announcements. We deviate from these in following ways. Rather than exchange rate as a market-determined asset price, we find it more suitable to directly study AE spillovers on the distance of EME RER from equilibrium since it is more responsible for global 
macro-distortions through trade. Most of the studies have not used the IMF Coordinated Portfolio Investment Survey (CPIS) database because the data here on capital flows to individual countries are annual (see MacDonald, 2017). Dedola et al. (2017) underscored the need for a more comprehensive study on the long term impacts of $\mathrm{QE}$, rather than only before-after type analysis of announcements/market activities. We use this data to gain a long term perspective on the impact of AE monetary policy both in normal and abnormal phases. Another novelty of this study is that we assess the relative impact of foreign policy against domestic objectives ${ }^{7}$. This can help to understand how much of RER misalignment is actually due to EME management.

To check for robustness of results, we use both multilateral as well as bilateral EME-US RER, and alternative estimation methods. We find robust evidence across specifications for AE monetary spillovers over the period of analysis (1998-2017) in the form of overvaluation in EME RER, even after controlling for most of the relevant EME specific factors. Portfolio rebalancing of US investors is a potential cause. There is evidence that EME policy favoured current account surpluses with the multilateral RER, but with the bilateral EME-US RER precautionary reserves policy is found to be more important.

The rest of the paper is laid out in five sections. Section II discusses the relevant literature. Data and methodology are elaborated on in Section III. Results are reported in Section IV along with robustness checks, while Section V concludes the paper.

\section{Literature}

The theoretical under-pinning in this paper is a simple static Mundell-Fleming (MF) type model with nominal rigidity (not derived from micro-foundations). An open economy achieves equilibrium only when the real, monetary and external sectors are balanced. The pivotal role in this model is played by the interest rate differential between home and abroad, which is determined by relative money supplies. In the presence of forex interventions (managed floating), we can assume imperfect capital mobility ${ }^{8}$. The three sectors in home country can be represented as:

Real: $\quad Y=C(Y-T)+I(i)+G+N X(e, Y)$

Monetary: $m=k Y+b i$

External: $N X(e, Y)+C F\left(i-i^{*}\right)=0$

$Y$ : income, $C$ : private consumption, $T$ : taxes, $I$ : investment, $i$ : real interest rate, $G$ : government expenditure, $N X$ : net exports, $e$ : RER, $m$ : real money supply, $k$ : response of real money demand to output, $b$ : response of real money demand to real interest rate, $C F$ : capital inflows, $i^{*}$ : real interest rate (abroad).

\footnotetext{
${ }^{7}$ Similar to Prabheesh et al. (2009) who analyze the relative impact of domestic mercantilist and precautionary policies on the deviations of Indian RER.

${ }^{8}$ In the presence of non-static expectations and a risk premium, the expected change in exchange rate covers the interest differential in the uncovered interest parity condition. But this does not hold when forex intervention reduces appreciation, foreign inflows continue since expected depreciation is inadequate to cover the interest differential.
} 
$C^{\prime}>0, I^{\prime}<0, N X^{\prime}(e)>0, N X^{\prime}(Y)<0, k>0, b<0, C F^{\prime}(i)>0$. Each equation in the EME has a counterpart equation in the $\mathrm{AE}$ with which it trades in goods and capital. Of particular interest in this paper on monetary spillovers, is the monetary sector abroad, e.g. $m^{*}=k Y^{*}+b i^{*}$ (here we assume the responses of real money demand to output and interest rate are same at home and abroad).

Using the monetary equations, interest rate differential, $i-i^{*}=\left(b^{-1}\right)\left(m-m^{*}\right)-\left(k . b^{-1}\right)\left(Y-Y^{*}\right)$. Thus, relative money supply between home and abroad determines the interest rate differential which in turn determines $C F$. When $m *$ increases more in proportion to $m$, the interest differential widens (since $b<0$ ) and hence, leads to more capital inflows. This means that domestic RER (e) has to appreciate to maintain equilibrium in the external sector through decline in $N X$. A country is constantly making choices to maintain both internal and external balances. Its instruments are primarily $e$ and $i$. Domestic output and employment objectives may motivate the home country to reduce the appreciation in $e$ to boost $N X$. A country can influence $e$ through intervention in the foreign exchange market, or through its money supply (interest rate channel), or through outright capital controls ${ }^{9}$. Thus, $e$ is determined in this MF type model by both foreign monetary policy, as well as the extent to which the country manages the $e$ for domestic mercantilist as well as precautionary objectives. We do not go into further theoretical modelling, but keep the focus on empirically studying the trade-off between foreign monetary policy and domestic policy objectives like $N X$, reserves or growth on the deviation of RER from its equilibrium.

Similar results are obtained in more complex microfounded models. For example, in the context of spillovers due to UMP, Alpanda and Kabaca (2020) show in a two-country dynamic general-equilibrium model that imperfect substitutability between long term and short term bonds in home country leads to portfolio rebalancing towards EMEs. The EME can be impacted through two channels, e.g. trade channel and financial channel. In the financial channel, portfolio effects pull down EME long term rates; lower rates stimulate EME demand. However, in the trade channel, increased volatile portfolio flows create appreciatory pressure on EME currency unless it is absorbed in reserves. This reduces exports, which is not compensated by the rise in AE imports from growth effects of UMP.

Two major groups of empirical studies have emerged on monetary spillovers, one studies the impact emanating from US UMP, the second studies ECB UMP (Fratzscher et al., 2016; Angelovska - Bezhoska et al., 2018). There have been many studies on differential effects of CMP vs. UMP, e.g. Chen et al. (2014) find that UMP had larger spillover for EMEs than CMP did, Georgiadis (2016) finds that countries affected more by CMP face larger disruptions during tapering. Bowman et al. (2014), Chen et al. (2014), Anaya et al. (2017) have analysed how unexpected changes in monetary policy have impacted EMEs. Kucharčuková et al. (2016) find that while CMP is more impactful on prices and output, UMP affects

\footnotetext{
${ }^{9}$ In this context, Rey (2013) has pointed out that large EME forex volatility during post-GFC years made any one of these instruments inadequate, even with floating exchange rates.
} 
exchange rates more. Since our data includes both CMP and UMP phases, our paper relates to this strand of the literature. In this regard, Lin et al. (2017) have studied the differential impact of the various phases of $\mathrm{QE}$ on EME macroeconomic variables (e.g. spot exchange rate, foreign exchange reserves, domestic credit, inflation etc.) and find that the first phase of QE was the most impactful on EME variables.

Methodologies used have varied from simple OLS (MacDonald, 2017) to VAR (Helbling et al., 2011; Kucharčuková et al., 2016; Tillman, 2016; Georgiadis, 2016; Anaya et al., 2017) to panel (Chen et al., 2014; Lim et al., 2014; Mishra et al., 2014; Aizenman, et al., 2014; Bowman et al.,2014; Fratzscher et al., 2016, Lin et al., 2017). Lim et al. (2014) conducts both panel regression as well as VAR. The methodology has been to regress impulse responses from monetary policy shocks in a VAR framework on country-specific characteristics. Another approach has been to directly regress EME variables on AE monetary variables. Dedola et al. (2017) take the size of the balance sheet of ECB relative to that of the Fed as a measure of relative QE shock to see its impact on exchange rate, while Anaya et al. (2017) also identify changes in monetary policy through the Central Bank balance sheet. Again, Chen et al. (2014) measure monetary policy in a simple method by assuming that the difference between the yield of the next expiring futures on Federal Funds rate taken just before an announcement and the target Federal Funds rate actually announced can capture monetary surprises. MacDonald (2017) also regresses EME asset prices on US balance sheet changes along with VIX. This paper follows the panel approach and regresses EME RER misalignments directly on variables reflecting changes in AE monetary policy.

Country heterogeneity has been considered in most of the papers, for example, Chen et al. (2014), Lim et al. (2014), Mishra et al. (2014) etc. MacDonald (2017) finds, in a sample of 21 EMEs over 2008-2014, there is considerable heterogeneity in the extent of currency appreciation following US QE which can be explained through bilateral capital-market frictions. Aizenman et al. (2014) find countries with stronger fundamentals show more appreciation during QE and more depreciation during tapering of QE because of higher exposure to capital inflows. They group EMEs into 'low' and 'high' groups, on the basis of criteria like international reserve holdings, current account surpluses and external debt. They construct a further grouping "robust" and "fragile" where "robust" countries are high on at least two of the above criteria. In analysing the effect of US UMP on EME asset prices and capital flows, Chen et al. (2014) include country fundamentals, both as standalone variables as well as interaction terms. Lim et al. (2014) uses country specific factors along with indicator variable that captures QE operations and variables to capture transmission channels. Mishra et al. (2014) take macroeconomic fundamentals like inflation, fiscal and current account balances, and reserves along with EME growth forecasts; they also include structural factors like financial depth, financial integration and exposure to China, and find better positions in respect to current account balance, inflation and reserves were key in containing market volatility around the tapering announcements of 2013. But Cerutti et al., (2019) find that rather than country fundamentals, the nature of $\mathrm{AE}$ investors and asset types can explain the sensitivities of EMEs to foreign capital inflows. 
Fratzscher et al. (2016) and Anaya et al. (2017) use institutional quality in order to explain the differences in EME responses. While the first paper, which includes AEs as well, finds institutional quality can explain the differences, the second paper, which studies only EMEs does not find any such effect. In addition, Anaya et al. (2017) also examine financial openness, geographical distance from the epicentre as well as exchange rate regimes. Tillman (2016) also takes geographical variables to explain variations. However, the significance of monetary policy is not universal. Angelovska-Bezhoska et al. (2018) study the impact of ECB UMP on capital flows in the central and eastern European region and find no significant impact. Anaya et al. (2017) finds evidence for the insignificance of country heterogeneity.

\section{Channels of transmission}

The injected liquidity in the AEs is found to make way into EMEs through some broad channels discussed in the transmission literature. Typically, the QE comprised of long term sovereign bond purchases, which crowded out investors from domestic markets. They looked for substitute investments, mainly in the EMEs. This has been called the portfolio rebalancing channel (Fratzscher et al., 2016; Weale and Wieladek, 2016). The primary effect is seen in falling yields in EMEs (MacDonald, 2017; Dedola et al., 2017). Another channel of transmission of UMP is the liquidity channel (Gagnon et al., 2011; Lim et al., 2014). An increased balance sheet of the Fed leads to an increased liquidity in the balance sheets of private banks in the US. This liquidity finds its way not only to domestic borrowers but also to borrowers in EMEs through international lending. Lim et al. (2014), Weale and Wieladek (2016) also discuss the importance of a signalling channel. Purchases can provide signals of continuing low interest rates. Prospects of recovery in the US economy can affect EMEs through building confidence in EME market players. Although we do not study transmission channels, our variables have been chosen on the basis of the standard literature on transmission channels. While we address the first two channels, the third channel of transmission is beyond the scope of this paper.

\section{Data and methodology}

Data

We use a balanced panel from 1998 to $2017^{10}$. The start year was restricted to 1995 because of data unavailability for China and Russia. Further computation of growth and inclusion of lags while modelling reduces the start year to 1998. The countries of the panel are the same as in (blinded for Double-blind peer review - BDBPR) since we use their estimates of misalignments in multilateral trade-weighted $\mathrm{RER}^{11}$ as our dependent variable (MSALIGN_MULT). These are Brazil, China, India, Indonesia,

\footnotetext{
${ }^{10}$ Studies with long term data are few. The nearest study is by Lim et al. (2014) who conduct an analysis of spillovers with capital flows over the period 2000-13.

${ }^{11}$ This paper provides estimates of equilibrium RER for eight large EMEs against four major AEs of US, UK, Japan and Australia using yearly EME-AE trade weights. Equilibrium RER is estimated as a function of structural variables like productivity, financial development, dependency ratio etc. using panel cointegration methods like
} 
Mexico, Russia, Thailand and Turkey. The RER is defined as relative price between foreign and home baskets, e.g. SP*/P. A negative movement in RER stands for overvaluation and vice-versa. Appendix Table A1 gives detailed descriptions of variables, abbreviations, data sources, along with unit root testing results.

Following the "push" and "pull" classification of variables in the literature on capital flows (AngelovskaBezhoska et al., 2018), we see the "pull" variables as EME specific variables, and the "push" variables as those beyond the control of EMEs. Cerutti et al. (2019) also categorises AE monetary policy as "push" factors. The "pull" variables can again be classified into two types, one, fundamentals that are structural or slow moving and two, EME policy that is responsive to growth outlook as well as external policy environment (IMF, 2013 discusses the temporary and permanent nature of variables).

EME specific variables, which are reported in different currencies as well as carry a size effect (e.g. foreign direct investment, sovereign debt, current account balance, reserves), had to be normalised with respect to country GDPs to make them comparable. The stationary panel analysis requires variables to be $\mathrm{I}(0)$. In most instances, our variables were found to be integrated of order one in levels, but stationary in differences ${ }^{12}$. For the sake of interpretation ease, we use log differences of these variables ${ }^{13}$. Variables, which are stationary in levels, the RER misalignment estimates, current account balance-to-GDP ratio and export diversification index, are taken in their original form. While computing growth in net foreign assets, we use the formula $\left(\mathrm{X}_{\mathrm{t}}-\mathrm{X}_{\mathrm{t}-1}\right) /$ absolute $\mathrm{X}_{\mathrm{t}-1}$. This ensures the correct sign since the data has negative figures in some years.

\section{Methodology}

Since the countries might differ due to inherent factors like historical growth, political preferences etc. that are largely time-invariant, we use fixed effects (FE) estimation ${ }^{14}$ which demeans the data to cancel out unobserved country-specific effects that may create a potential omitted variable bias.

The benchmark specification is:

$$
Y_{i t}=\mu_{i}+\beta_{m} M_{i t}+\sum_{j=1}^{K} \beta_{c j} C_{i t, j}+\sum_{p=1}^{M} \beta_{d p} D_{i t, p}+\varepsilon_{i t}
$$

FMOLS and DOLS. Coefficient estimates do not vary much between the two methods. The RER misalignment is then calculated in percentage terms. We use the DOLS based estimates because of their greater efficiency.

${ }^{12}$ We use the Levin-Lin-Chu (2002) panel unit root test which has good small sample properties (Appendix Table A1).

${ }^{13}$ A prefix of DL indicates growth in that variable.

${ }^{14}$ Endogeneity can be a problem with FE if the panel is dynamic in nature e.g. regressors include lagged dependent variable particularly in the "small T large N" case (Nickell, 1981) leading to inconsistent parameter estimates. Since ours is a non-dynamic long panel, FE is preferred. Chinn et al. (2013) also note that FE regression is more suitable for panels of non-dynamic nature. 
$\mathrm{Y}_{\text {it }}$ is misalignment in domestic EME RER from equilibrium. $\mu_{i}$ are the unobserved FE. $\mathrm{M}_{\text {it }}$ is AE monetary policy variable. $C_{i t, j}$ takes into account $j^{\text {th }}$ EME specific control. $D_{i t, p}$ stands for $p^{\text {th }}$ deterministic term. $\beta_{m}, \beta_{c_{j}}, \beta_{d_{p}}$ capture their respective coefficients. The residuals $\varepsilon_{i t}$ are assumed to be i.i.d.

Five measures are taken in $\mathrm{M}_{\mathrm{it}}$, all in growth form. First, gross asset holdings of US portfolio investors across all sectors in each EME (DL_ASTS_US). This data is from IMF CPIS. Portfolio flows data is published as assets or liabilities holdings by reporting nation in target nations ${ }^{15}$. In the absence of publicly available long series on cross-border banking data, the yearly change in this series is a good proxy for the capital inflows into EMEs due to portfolio rebalancing in the US.

Second, US broad money (DL_M2_US). This includes narrow money (e.g. transferable deposits and currency in circulation) and quasi money (e.g. time, savings deposits and foreign currency deposits) (IFS line 351). Third, weighted ${ }^{16}$ broad money (DL_WT_M2) across US, UK and Japan. Both these variables capture the general increase in the balance sheet of the AE Central Banks (liquidity channel). Although the RER estimates in $(B D B P R)$ are based on US, UK, Japan and Australia, we could take weighted average of broad money in three of these countries ${ }^{17}$, which did adopt QE in the post crisis years. We could not include ECB in the analysis due to lack of annual series on a long range.

Monetary policy in AEs moves in tandem with market volatility measured by VIX ${ }^{18}$ (Rey, 2013). We therefore take the annual geometric mean of daily VIX figures (VIX_GM) as our fourth measure. Chen et al. (2014) has used this variable as investor's risk appetite and found significant spillovers. CPIS assets data can be categorised into equity and debt. Cerutti et al. (2019) find that asset type can be an important factor in spillovers. Hence, the final variable we consider is US debt assets holdings (DL_DEBTASTS_US) which shows the comparatively riskier component of the gross assets. If the debt assets holdings are significant, we can form an idea about how foreign credit risk can influence imbalances in EME RER.

The domestic control variables $\mathrm{C}_{\mathrm{it}}$ are grouped into: 1) fundamentals/vulnerabilities (permanent "pull" factors), and 2) domestic policy variables (temporary “pull”).

\footnotetext{
${ }^{15}$ The sectoral data by investor type like Central Bank, banks, etc. are available for only 3-4 years. The lack of Chinese data on assets and liabilities before 2015 restricted us from using the measure of net assets holdings.

${ }^{16}$ We use annual trade weights sourced from BDBPR.

${ }^{17}$ Australia did not adopt any large scale asset purchases during this period.

${ }^{18}$ VIX data is published by the Chicago Boards Option Exchange based on market expectations of stock market volatility in the next 30 days. Their calculations are based on S\&P 500, the benchmark measure of US stock market. The VIX estimates are assumed to reflect the risk in international financial markets.
} 
Fundamentals: Growth in real GDP (REAL_G), growth in net foreign direct investment-to-GDP ratio (inflows - outflows) (DL_NETFDI);

Vulnerabilities: Growth of gross sovereign debt-to-GDP ratio (DL_SOVDEBT_Y), CPI inflation (INF_CPI), interest differential (INT_DIFF).

Mercantilist policy: Current account balance-to-GDP ratio (CAB_GDP), index of export diversification $(\text { EX_DIV })^{19}$.

Precautionary policy: International reserve-to-GDP ratio growth (DL_RESERVES_Y) and net foreign assets growth (DL_NFA).

A dummy variable DUM_UMP (1 for UMP years i.e. 2009 to 2014,0 otherwise) ${ }^{20}$ is taken to test the stability of the relationship across UMP and CMP phases. This can give valuable insights into the asymmetry of monetary policy spillovers. Descriptive statistics of these variables are reported in Appendix tables A2 and A3.

As a measure of vulnerability, we include the interest rate differential of EMEs with respect to US. A higher differential indicates larger risk premium ascribed to an economy by investors. However, this can also lead to overvaluation, since capital inflows are attracted by higher differentials in the MF model, if overshooting of the exchange rate is prevented. Which effect is prominent is to be seen.

Bowman et al. (2014) have controlled for macro-variables like real growth, gross capital formation, inflation, government debt-to-GDP ratio. They take credit-GDP ratio as a measure of bank vulnerability. We have avoided taking gross capital formation and credit to GDP ratio since they entered the estimation of the equilibrium RER in $(B D B P R)$. As a measure of heterogeneity, both Aizenmann et al. (2014), Bowman et al. (2014) have used current a/c deficit. However, we refrain from grouping it under controls but consider it a mercantilist variable. Bowman et al. (2014) takes total exports to the U.S. to GDP ratio as a variable that captures linkage with AE. On similar lines, we tried merchandise exports to highincome economies (as a percentage of total merchandise exports). However, we observed high correlation between the current a/c balance and percentage of merchandise exports to high-income economies. So the latter variable was dropped from the analysis.

To understand the extent of precautionary reserves accumulation, we take the change in reserves as a ratio of GDP (DL_RESERVE_Y). DL_NFA ${ }^{21}$ is taken as a proxy for net international assets. A growth in this

\footnotetext{
${ }^{19}$ Data is from IMF Export Diversification Database.

${ }^{20}$ DUM_UMP is constructed based on Papadamou et al. (2019) where QE1 is from November 2008 to March 2010 , QE2 from November 2010 to June 2011, and QE3 from September 2012 to October 2014. Since these are monthly data while ours is annual data, we take the next year if the date is in the second half of the year. We date the UMP phase from 2009 to 2014.

${ }^{21}$ Net foreign assets is defined as assets (outflows) less liabilities (inflows).
} 
term would mean EMEs investing more abroad than receiving. This reduces the appreciatory pressure on RER and hence requirement of precautionary holding of reserves.

\section{Correcting standard errors}

The errors in a panel estimation might potentially be heteroskedastic and serially correlated (see Arellano 1987) making statistical inferences inconsistent. Again, observations from a similar environment can form clusters in a panel, which can be mutually independent. This renders FE estimation inconsistent (Moulton, 1990). We address these issues using cluster-robust ${ }^{22}$ heteroscedasticity and autocorrelation consistent (HAC) standard errors.

In our data neighbouring countries might be impacted by similar shocks, giving rise to the possibility of geographical region-wise clusters ${ }^{23}$. Moreover, Moulton (1990) observes that when firm level data are regressed on industry-level variables, this too can result in downward biased standard errors and higher probability of rejection of the true null. Since some of the monetary variables we study are aggregate in nature while the outcome variable, RER misalignment, is EME-specific, we believe the estimation may suffer from cluster-bias. Moreover, with a considerably long time span there is possibility of correlation over years for the same individual, the time-wise cluster. Peterson (2009) discusses elaborately on methods applied to estimate correct standard errors in presence of clusters as well as non-diagonal variance-covariance matrices. We use the method of Thompson (2011) that addresses both cross-sectional and time wise clusters by a simple technique of subtracting heteroscedasticity and serial correlationrobust ordinary least squares covariance matrix from the sum of both state as well as time clustered covariance matrices. The method first obtains parameter estimates through FE estimation without any clustering, and then obtains "cluster" robust SEs using the method of Arellano (1987) for linear panel models. We corrected the robust standard errors for small sample size keeping in mind that the number of clusters may not be large enough.

We also apply the pooled mean group (PMG) procedure to differentiate between long and short run relationship in specification III.1. EMEs might come under the influence of domestic business cycles, technological shifts, various tax, agricultural or banking policies mainly effective in the short run, whereas, we can expect a convergence in parameters in the long run. Pesaran et al. (1999) argue that

\footnotetext{
${ }^{22}$ Clustering occurs when residuals are correlated for individuals in a group, but uncorrelated between different groups leading to inconsistent statistical inference (see Petersen, 2009). Bertrand et al. (2004) points to the need of correcting for clusters even after FE transformation.

${ }^{23} \mathrm{We}$ ran pooled OLS including a dummy that differentiated Asian from non-Asian countries (group $=1$ if the $\mathrm{i}^{\text {th }}$ nation is located in Asia, 0 otherwise). With the different $\mathrm{AE}$ variables, this dummy was found to be negative in sign and highly significant indicating that Asian nations had inherently more overvalued RER (online Reference 1). The exercise lent support to the hypothesis that the data could contain clusters.
} 
while the long run relationship is often found to be averaged and identical ${ }^{24}$, it is too strong an assumption for the short run. They show that the PMG estimator is consistent as well as asymptotically normal with stationary regressors. This approach has been applied to understand other macro-relationships for example, Ezeaku et al. (2019) uses PMG to understand if there is homogeneity in the link between foreign aid and economic growth.

To check the robustness of the analysis, we change the dependent variable from misalignment in multilateral RER to that in bilateral $\mathrm{RER}^{25}$ against US. The regressors are kept same for comparison purpose. The series on assets and debt assets holdings could be constructed only for US making it imperative to study how the bilateral RER against US is impacted. We estimate country-specific EME US RER trend values using Hodrick Prescott (HP) filter ${ }^{26}$. Then we calculate deviations from trend as [Actual RER/ Trend RER - 1 ] * 100. We call this RER_DEV. In a recent paper Hamilton (2017) expresses reservations on the HP filter and proposes the use of a simple method of trend estimation ${ }^{27}$. Hence, we also calculate the deviations in RER from the Hamilton trend (RER_DEVH). Figures 3 A and B below plot the misalignment in trade weighted multilateral RER (MSALIGN_MULT) against the constructed measures of misalignment in bilateral RER e.g. RER_DEV and RER_DEVH for the sample.

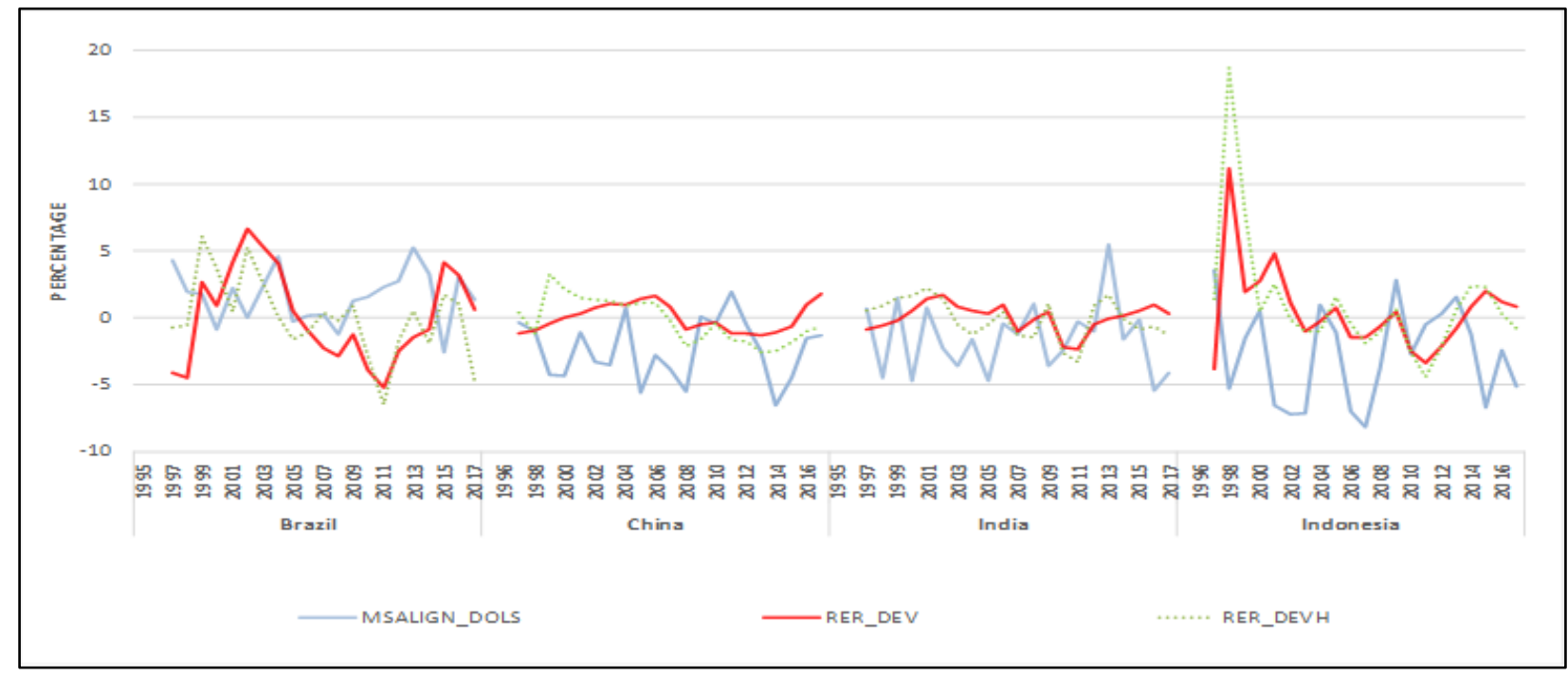

Figure 3A: Dependent variables (Brazil, China, India, Indonesia)

\footnotetext{
24 "There are often good reasons to expect the long-run equilibrium relationships between variables to be similar across groups, due to budget or solvency constraints, arbitrage conditions, or common technologies influencing all groups in a similar way.” Pesaran, Shin and Smith (1999), p. 621.

${ }^{25}$ Based on Consumer Price Index.

${ }^{26}$ We use a $\lambda$ value (frequency) of 100 as is normally used for annual data in the HP filter method. We do not include any drift in the model.

${ }^{27}$ Trend is estimated by fitting any univariate series on four consecutive past values, each lagged by two years from the previous value. In annual data, this is done by estimating each series on $2^{\text {nd }}, 3^{\text {rd }}, 4^{\text {th }}$ and $5^{\text {th }}$ lags. We include no drift similar to HP estimation.
} 


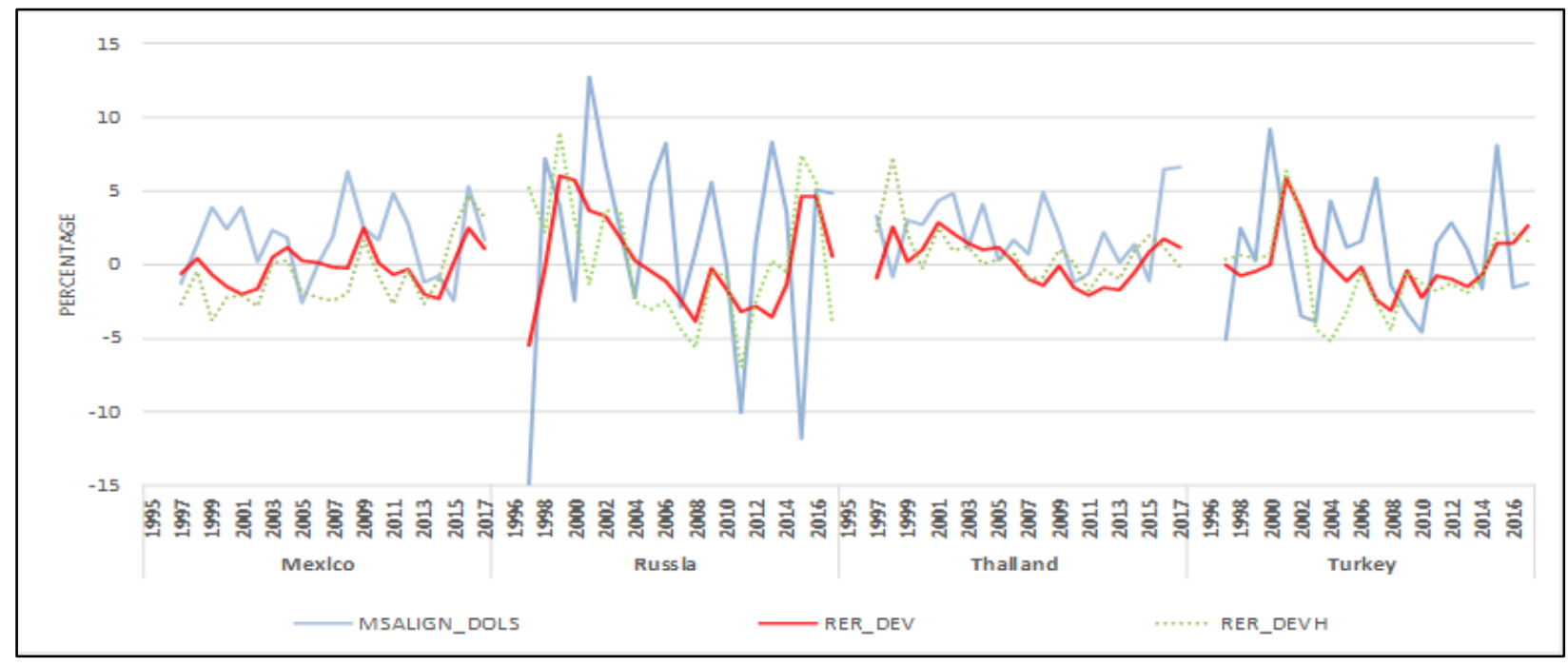

Figure 3B: Dependent variables (Mexico, Russia, Thailand, Turkey)

Fig 3. Dependent variable: RER misalignment as percentage of equilibrium RER

Source: MISALIGN_MULT: sourced from (blinded for peer review); RER_DEV and RER_DEVH: Authors' calculations.

As a third check, we use the common correlated effects (CCE) estimator (Pesaran, 2006) that accounts for unobserved common factors by running auxiliary regressions augmented with the averages of the dependent variable as well as regressors. The CCE estimator has good small sample properties and can be applied on FE models with consistent estimates.

In terms of model III.1, the presence of common unobserved effects denoted by $\mathrm{f}_{t}$ can be captured through the residuals $\varepsilon_{\text {it }}$, which are not iid anymore:

$\varepsilon_{i t}=\lambda_{i}^{\prime} f_{t}+u_{i t}$

Here $\lambda_{\mathrm{i}}$ captures factor loadings that differ across units.

Pesaran (2006) shows that $\mathrm{f}_{\mathrm{t}}$ can be proxied by the cross-section averages of dependent and independent variables for each year. The benchmark specification III.1 can now be augmented as:

$Y_{i t}=\beta_{m} M_{i t}+\sum_{j=1}^{K} \beta_{c j} C_{i t, j}+\sum_{p=1}^{M} \beta_{d p} D_{i t, p}+\lambda_{Y} Y_{b a r}+\lambda_{m} M_{b a r}+\sum_{j=1}^{K} \lambda_{c j} C_{b a r_{j}}+u_{i t}$

where $Y_{b a r}, M_{b a r}$ and $C_{b a r}$ are the averages of dependent, monetary and domestic control variables over individuals for any given year.

\section{Results}

IV.1. FE estimation: trade-weighted multilateral RER against US, UK and Japan 
Whether FE estimation is significantly better than OLS was checked using the Breusch Pagan Lagrange Multiplier (BPLM) test which provided evidence in favour of $\mathrm{FE}^{28}$. Additionally, a BPLM type test for significant time effects was rejected for each model indicating individual effects is more suited (Appendix Table A4). Hence, we use individual rather than time effects. We model III.1 keeping the EME controls same, but varying the AE monetary policy variables. It is specified as below:

$M S A L I G N \_M U L T_{i t}=\mu_{i}+\beta_{m}(A E \text { Monetary Policy })_{i t}+\beta_{c 1} R E A L \_G_{i,(t-1)}+\beta_{c 2} D L \_S O V D E B T \_Y_{i,(t-1)}$ $+\beta_{c 3} D L \_N E T F D I_{i t}+\beta_{c 4} C A B \_G D P_{i,(t-2)}+\beta_{c 5} E X_{-} D I V_{i t}+\beta_{c 6} D L \_N F A_{i t}+\beta_{c 7} D L \_R E S E R V E_{-} Y_{i t}$

$+\beta_{p} D U M_{-} U M P_{i t}+\varepsilon_{i t}$

Table I: Fixed Effects Estimates with Multilateral EME RER against US, UK, Japan and Australia

\begin{tabular}{|c|c|c|c|c|c|}
\hline \multicolumn{6}{|c|}{$\begin{array}{l}\text { Fixed effects estimation (1998-2017) } \\
\text { Dependent variable: Multilateral RER Misalignment (source: blinded for Double-blind peer review) }\end{array}$} \\
\hline & (IV.1A) & (IV.1B) & (IV.1C) & (IV.1D) & (IV.1E) \\
\hline DL_ASTS_US & $\begin{array}{l}-1.685 * * \\
(0.681)\end{array}$ & & & & \\
\hline DL_M2US & & $\begin{array}{l}5.010 \\
(10.724)\end{array}$ & & & \\
\hline DL_WT_M2 & & & $\begin{array}{l}-11.001 \\
(10.326)\end{array}$ & & \\
\hline VIX_GM & & & & $\begin{array}{l}-0.009 \\
(0.042)\end{array}$ & \\
\hline DL_DEBTASTS_US & & & & & $\begin{array}{l}-0.375 \\
(0.416)\end{array}$ \\
\hline lag(REAL_G, 1) & $\begin{array}{l}-6.918 * * \\
(2.743)\end{array}$ & $\begin{array}{l}-6.440 * * \\
(2.691)\end{array}$ & $\begin{array}{l}-6.017 * \\
(3.107)\end{array}$ & $\begin{array}{l}-6.075 * * \\
(2.705)\end{array}$ & $\begin{array}{l}-6.092 * * \\
(2.692)\end{array}$ \\
\hline lag(DL_SOVDEBT_Y, 1) & $\begin{array}{l}-12.234 * * * \\
(4.589)\end{array}$ & $\begin{array}{l}-11.037 * * \\
(4.830)\end{array}$ & $\begin{array}{l}-11.328 * * \\
(5.284)\end{array}$ & $\begin{array}{l}-10.699 * * \\
(4.698)\end{array}$ & $\begin{array}{l}-10.850 * * \\
(4.570)\end{array}$ \\
\hline DL_NETFDI & $\begin{array}{l}-0.113 * * * \\
(0.043)\end{array}$ & $\begin{array}{l}-0.125^{* * * *} \\
(0.037)\end{array}$ & $\begin{array}{l}-0.087 \\
(0.061)\end{array}$ & $\begin{array}{l}-0.095^{*} \\
(0.053)\end{array}$ & $\begin{array}{l}-0.095^{*} \\
(0.051)\end{array}$ \\
\hline lag(CAB_GDP, 2) & $\begin{array}{l}0.302 * * * \\
(0.070)\end{array}$ & $\begin{array}{l}0.243 * * * \\
(0.061)\end{array}$ & $\begin{array}{l}0.257 * * * \\
(0.067)\end{array}$ & $\begin{array}{l}0.271 * * * \\
(0.074)\end{array}$ & $\begin{array}{l}0.267 * * * \\
(0.066)\end{array}$ \\
\hline EX_DIV & $\begin{array}{l}1.505 \\
(1.766)\end{array}$ & $\begin{array}{l}0.973 \\
(1.349)\end{array}$ & $\begin{array}{l}1.010 \\
(1.607)\end{array}$ & $\begin{array}{l}0.972 \\
(1.535)\end{array}$ & $\begin{array}{l}1.050 \\
(1.557)\end{array}$ \\
\hline G_NFA & $\begin{array}{l}0.291 * \\
(0.152)\end{array}$ & $\begin{array}{l}0.203 \\
(0.191)\end{array}$ & $\begin{array}{l}0.219 \\
(0.214)\end{array}$ & $\begin{array}{l}0.253 \\
(0.190)\end{array}$ & $\begin{array}{l}0.251 \\
(0.182)\end{array}$ \\
\hline lag(DL_RESERVE_Y,0) & $\begin{array}{l}3.529 \\
(2.421)\end{array}$ & $\begin{array}{l}1.301 \\
(1.917)\end{array}$ & $\begin{array}{l}1.783 \\
(1.667)\end{array}$ & $\begin{array}{l}1.835 \\
(1.539)\end{array}$ & $\begin{array}{l}1.844 \\
(1.604)\end{array}$ \\
\hline dum_ump & $\begin{array}{l}1.534 * \\
(0.845)\end{array}$ & $\begin{array}{l}1.666 * * \\
(0.696)\end{array}$ & $\begin{array}{l}1.292 * \\
(0.757)\end{array}$ & $\begin{array}{l}1.316 \\
(0.945)\end{array}$ & $\begin{array}{l}1.344 \\
(0.906)\end{array}$ \\
\hline DL_M2US:INT_DIFF_MMR & & $\begin{array}{l}0.757 * * * \\
(0.275)\end{array}$ & & & \\
\hline DL_WT_M2:INT_DIFF_MMR & & & $\begin{array}{l}0.909 * \\
(0.491)\end{array}$ & & \\
\hline Observations & 152 & 152 & 152 & 152 & 152 \\
\hline Within R2 & 0.174 & 0.169 & 0.173 & 0.146 & 0.147 \\
\hline Adjusted R2 & 0.076 & 0.063 & 0.068 & 0.045 & 0.046 \\
\hline F Statistic & $\begin{array}{l}3.159 * * * \\
(\mathrm{df}=9 ; 135)\end{array}$ & $\begin{array}{l}2.719 * * * \\
(\mathrm{df}=10 ; 134)\end{array}$ & $\begin{array}{l}2.808 * * * \\
(\mathrm{df}=10 ; 134)\end{array}$ & $\begin{array}{l}2.569 * * * \\
(\mathrm{df}=9 ; 135)\end{array}$ & $\begin{array}{l}2.595 * * * \\
(\mathrm{df}=9 ; 135)\end{array}$ \\
\hline
\end{tabular}

\footnotetext{
${ }^{28}$ The BPLM tests the null of insignificant FE. If rejected, FE modelling is correct.
} 
We arrive at five specifications IV.1 A to E for each of DL_ASTS_US, DL_M2_US, DL_WT_M2, VIX_GM, DL_DEBTASTS_US. This kind of estimation using different regressions for different choices of monetary variable has earlier been used in Chen et al. (2014). CPI based inflation, which was initially hypothesized as a country specific control, was eventually excluded because it was insignificant and also increased model standard error. In each of our estimations we find that monetary policy and reserve policy variables have contemporaneous effects, while variables capturing fundamentals and CAB_GDP are significant only in lags. This is not unexpected, since the transmission of monetary policy is generally complete within a year, while real sector variables move with a larger momentum.

As in Aizenman et al. (2014) we tried interacting EME controls with AE monetary policy variables. Such interactive effect is absent. So we take them standalone. However, in specifications with unweighted and weighted broad money variables DL_M2_US and DL_WT_M2, we find that an interaction term between the AE monetary policy variable and interest rate differential between US and EME money market rates ${ }^{29}$ gives regressions more explanatory power. Standalone interest rate differential was found to be insignificant. Table I reports the results of the five estimations along with cluster-robust HAC standard errors.

\section{AE monetary variables ("push” factors)}

The Mundell-Fleming model in Section II shows that rising AE money supply relative to EMEs can cause spillovers through the capital inflows channel. This pushes up the domestic currency value. But the impact on domestic RER is more indirect, as this should be determined by internal factors that determine prices as well as the amount of mercantilist/precautionary intervention in checking the nominal appreciation. Studies like Tillmann (2016) and Weale and Wieladek (2016) find an appreciation impact on nominal exchange rates. Here we study the impact of spillovers on multilateral RER. We test whether AE monetary policy can cause significant RER misalignments from a fundamental-driven equilibrium, after accounting for other plausible factors. In the short term when prices are more or less rigid, the appreciatory pressure should translate to an over-valuation (negative coefficient).

In Table I, we find support for the hypothesized negative monetary spillovers on RER from the significant negative coefficient estimate of DL_ASTS_US i.e. growth in EME assets holdings by US portfolio investors which was held to capture portfolio rebalancing of $\mathrm{AE}$ investors. A one percent increase in the same overvalues the multilateral RER by around 1.7 per cent which is quite large in relative terms. This provides evidence that the portfolio rebalancing is an important channel of spillovers and a significant source of distortion in RER for the EMEs, as argued in Alpanda and Kabaca (2020).

\footnotetext{
${ }^{29} \mathrm{We}$ test for both lending and money market interest rate differentials. Only the latter provides significant results.
} 
We do not find a significant impact on multilateral RER from the liquidity channel, captured through growth in weighted (US, UK and Japan) and unweighted (US) broad monies (DL_WT_M2 and DL_M2US). However, here we find a significant positive pressure from the interactive effect between EME-AE interest differential and each of DL_WT_M2 and DL_M2_US. This shows that, contrary to common perceptions that interest differential drives capital inflows and appreciates exchange rate, in the RER of large EMEs it captures risk premium of an EME and can offset a part of AE monetary spillovers. Excess AE liquidity is not channelized to those nations with higher risk premium thus offsetting a part of the over-valuation from monetary spillovers. Thus "push" factor (AE monetary policy) in RER misalignment can be influenced by "pull” factor like EME vulnerability. Theoretically, this effect follows from the uncovered interest parity condition in the presence of forex intervention, which reduces the expected change in nominal exchange rate and hence the interest differential approximates the risk premium. This finding is supported by Lin et al. (2017) who also find that domestic EME interest rates positively impact spot exchange rates against US Dollar.

Both Aizenman et al. (2014) and Chen et al. (2014) find that risky debt inflows to EMEs had seen largest surge in the UMP period. Risky flows increase the default risk of a nation and hence increase volatility. To test if growth in the risky component of portfolio flows could yield any substantial information about multilateral RER misalignments, we take growth in debt assets holdings (DL_DEBTASTS_US) but find it to be insignificant ${ }^{30}$.

We also tested for impact of market volatility measure, VIX, on RER misalignment. VIX is commonly taken as a measure of near-term market volatility and may capture policy uncertainty as well (Tiwari et al. 2019). Several studies recently show that monetary policy in AEs is influenced by uncertainty (Rey, 2013; Cekin et al., 2020). Cekin et al. (2020) show that monetary policy can co-move with market uncertainty. Hence, a higher VIX may change the course of AE monetary policy. However, unlike Chen et al. (2014), which find VIX to be significant on EME nominal exchange rates, we do not find any significant impact from VIX indicating that market volatility may not be a strong factor in a real relative price like RER.

EME specific controls ("permanent pull" factors)

Next, we see the coefficients of fundamentals/vulnerabilities. They control for the role of country-specific characteristics in RER misalignments. Fundamentals (vulnerabilities) are hypothesized to over- (under-) value RER. These coefficients lie in a close range across the five models. As expected, real and net FDI growth (REAL_G and DL_NETFDI) over-value the multilateral RER. This is similar to Aizenman et al.

\footnotetext{
${ }^{30} \mathrm{We}$ also tried to see if RER misalignment could be explained by share of debt holdings in total holdings, either standalone or through interactive effect. However, this too is insignificant.
} 
(2014) who find that robust fundamentals attract capital inflows and lead to exchange rate appreciation during QE period.

Sovereign debt ratio (DL_SOVDEBT_Y) was taken to capture vulnerability since high sovereign debt levels have been historically seen to culminate in economic crises. However, rather than under-valuation, this too overvalues RER, behaving similar to a fundamental. It will be useful to note that sovereign debt can capture the possibility of 'crowding out' of private borrowing by large government borrowing requirements and may be leading to more private borrowings abroad, although government borrowing abroad is itself capped. So this might be capturing the underlying external debt. This resonates with Aizenman et al. (2014) who find that high external debt can result in appreciation. This is a hypotheses and remains to be tested in future work.

Overvaluation from domestic "pull" factors like real GDP growth (- 6 to -7 percent) is much larger in comparison to "push" factor of AE monetary policy (-1.7 percent). Overvaluation impact of sovereign debt growth is almost double the impact of real GDP growth. In comparison, the impact of DL_NETFDI is negligible.

\section{EME policy variables ("temporary pull” factors)}

Variables capturing mercantilist/precautionary objectives like CAB_GDP, EX_DIV, DL_RESERVE_Y, DL_NFA are hypothesized to under-value RER. Mercantilist policy (CAB_GDP), i.e. the motive to acquire surpluses on the current account, undervalues the RER at a high level of significance across the models, but with lag. Its significance in current period is not obtained in any case. Its undervaluation impact, in the range of 0.24 to 0.3 percent, is small compared to AE monetary variables. Export diversification (EX_DIV) as well as precautionary reserves (DL_RESERVES_Y) are insignificant. We find a significant positive impact of DL_NFA only with portfolio rebalancing channel (model IV.1 A). This captures the volatility arising from gross flows with the rest of the world. By the definition of net foreign assets, an increase over last period is equivalent to a fall in gross capital inflows and should reduce the appreciation pressure on RER. This would mean a positive coefficient.

\section{Standard vs. non-standard monetary policy}

The dummy variable capturing UMP years 2009-14 (DUM_UMP) is found to be significant and positive in three models (1.2 to 1.6 percent) with a p-value $<0.05$ indicating, with other factors unchanged, EME RER was more undervalued during the UMP phase. This particular finding needs to be analysed keeping in mind that while the other coefficients give the average impact of explanatory variables on RER misalignment over the entire period, DUM_UMP captures the vertical shift in the regression line in the years 2009-14. This vertical shift shows the time effect on the multilateral RER and is possibly capturing 
the downward pressure on EME RERs during this period, when the EMEs were more prone to hot money flows (Lin et al., 2017) as well as saw risk-off episodes due to tapering.

\section{Economic implications}

The results show that spillovers on EME RER from AE conventional monetary policy could considerably over-value it over the period of study 1998-2017. Portfolio rebalancing is the most prominent channel. Thus expansionary AE monetary policy can potentially help to reduce current account deficits in AEs by decreasing EME competitiveness, while it may hurt growth and recovery in EMEs. However, to what extent the impact actually passes through to domestic output is a matter of another study, possibly using VAR on output and RER. This study also shows that excess/unconventional monetary expansion to boost $\mathrm{AE}$ growth can be counter-intuitive since this might lead to more focus on containing excess volatility and hence significantly under-value EME RERs in response.

\section{IV.2. Pooled Mean Group Estimation}

The PMG procedure (Pesaran et al. 1999) allows to differentiate between heterogeneous short run relationship between the explained and explanatory variables, while homogeneity of slope coefficients is retained in the long run. Whether the PMG estimates are significantly better is checked using Hausman specification test ${ }^{31}$. Since the null of homogeneity restriction is not rejected, PMG can efficiently and consistently estimate the true parameters of the model.

The short run equations are estimated on the basis of the long run relationship. This in turn is taken from specification IV.1. Dummy and interaction terms cannot be differenced, and hence have to be excluded. We use the AE monetary variable DL_ASTS_US which was found to be significant in the FE estimation.

\section{Modified long run relationship:}

$M S A L I G N \_M U L T \sim f\left(D L \_A S T S \_U S, R E A L \_G(-1), D L \_S O V D E B T(-1), D L \_N E T F D I, C A B \_G D P(-2)\right.$,

$E X \_D I V, D L \_N F A, D L \_R E S E R V E S \_Y$ )

To simplify (IV.2), let us denote the eight exogenous regressors as $\mathrm{Xp}_{\mathrm{it}}=\left(\mathrm{X}_{1 \mathrm{it}}, \mathrm{X}_{2 \mathrm{it}}, \ldots, \mathrm{X}_{8 \mathrm{it}}\right)$, where $\mathrm{p}=1$ to 8. Following Pesaran et al. (1999), who take a single lag in the ARDL representation, the above model in ARDL form can be written as:

$$
Y_{i, t}=\mu_{i}+\lambda_{i} Y_{i(t-1)}+\theta_{10 i} X_{1 i t}+\theta_{20 i} X_{2 i t}+\theta_{30 i} X_{3 i t}+\theta_{40 i} X_{4 i t}+\theta_{50 i} X_{5 i t}+\theta_{60 i} X_{6 i t}
$$

\footnotetext{
${ }^{31}$ It tests the null of joint homogeneity of slope coefficients (PMG) against heterogeneity i.e. mean group (MG) estimator which allows slopes and intercepts to vary across cross-section. It uses a $\chi^{2}$ statistic. If rejected MG is better, otherwise PMG. Based on specification IV.2 with eight regressors, we find that the null is accepted with a $\chi^{2}$ $(\mathrm{df}=8)$ of $2.13(\operatorname{prob}(2.13)=0.98>0.05)$.
} 


$$
\begin{aligned}
& +\theta_{70 i} X_{7 i t}+\theta_{80 i} X_{8 i t}+\theta_{11 i} X_{1 i,(t-1)}+\theta_{21 i} X_{2 i,(t-1)}+\theta_{31 i} X_{3 i,(t-1)}+\theta_{41 i} X_{4 i,(t-1)} \\
& +\theta_{51 i} X_{5 i,(t-1)}+\theta_{61 i} X_{6 i,(t-1)}+\theta_{71 i} X_{7 i,(t-1)}+\theta_{81 i} X_{8 i,(t-1)}+\varepsilon_{i t}
\end{aligned}
$$

Some manipulation, as shown in equation (IV.4.), leads to the error correction representation in (IV.5) which is estimated using maximum likelihood (ML) method.

$$
\begin{gathered}
Y_{i, t}-Y_{i,(t-1)}=\mu_{i}-\left(1-\lambda_{i}\right) Y_{i(t-1)}+\left[\theta_{10 i} X_{1 i t}+\theta_{11 i} X_{1 i t}\right]+\ldots \ldots \ldots+\left[\theta_{80 i} X_{8 i t}+\theta_{8 I i} X_{8 i t}\right]+ \\
{\left[\theta_{11 i} X_{1 i,(t-1)}-\theta_{11 i} X_{1 i t}\right]+\ldots \ldots \ldots \ldots \ldots \ldots \ldots \ldots \ldots \ldots+\left[\theta_{81 i} X_{8 i,(t-1)}-\theta_{81} X_{8 i t}\right]}
\end{gathered}
$$

or, $\Delta Y_{i, t}=\Gamma_{i}\left(Y_{i(t-1)}-\rho_{0}-\sum_{p=1}^{8} \rho_{p} X_{p, i t}\right)-\sum_{p=1}^{8} \theta_{p 1, i} \Delta X_{p, i t}+\varepsilon_{i t}$

\begin{tabular}{|c|c|c|c|c|c|c|c|c|c|}
\hline \multirow[t]{2}{*}{ Coefficients } & \multirow{2}{*}{$\begin{array}{c}\text { Long } \\
\operatorname{run}\left(\rho_{p}\right)\end{array}$} & \multicolumn{8}{|c|}{ Short run $\left(\theta_{p 1, i}\right)$} \\
\hline & & Brazil & China & India & Indonesia & Mexico & Russia & Thailand & Turkey \\
\hline \multirow{2}{*}{$\begin{array}{l}\text { Error Correction } \\
\text { Coefficient }\left(\Gamma_{\mathrm{i}}\right)\end{array}$} & & $-0.866^{* * * *}$ & $-0.812 * * *$ & $-0.924 * * *$ & $-0.654 * * *$ & $-0.501 * * *$ & $-1.626^{* * *}$ & $-1.555^{* * *}$ & $-0.942 * * *$ \\
\hline & & $(0.31)$ & $(0.15)$ & $(0.16)$ & $(0.20)$ & $(0.18)$ & $(0.16)$ & $(0.41)$ & $(0.20)$ \\
\hline \multirow[t]{2}{*}{ DL_ASTS_US } & 0.619 & 0.312 & $-2.612 * * *$ & $-4.756^{* *}$ & $3.844^{13 \%}$ & $-5.665^{* * *}$ & -2.141 & -0.658 & -2.367 \\
\hline & $(0.82)$ & $(1.52)$ & $(0.86)$ & $(1.88)$ & $(2.55)$ & (1.97) & $(2.06)$ & $(0.99)$ & $(2.03)$ \\
\hline \multirow[t]{2}{*}{ lag(REAL_G, 1) } & $-7.076 * * *$ & $6.857^{* *}$ & 9.589 & $-30.629 * * *$ & -0.457 & -1.664 & -3.950 & -1.447 & -11.963 \\
\hline & $(2.14)$ & $(3.21)$ & (8.98) & $(6.71)$ & $(3.95)$ & $(4.01)$ & (3.64) & (7.56) & $(9.00)$ \\
\hline \multirow{2}{*}{$\begin{array}{l}\text { lag(DL_SOVDEBT_Y, } \\
\text { 1) }\end{array}$} & $-9.029 * * *$ & 6.261 & -5.258 & -19.917 & $7.470^{13 \%}$ & $11.457^{*}$ & 2.570 & $6.606^{11 \%}$ & -6.295 \\
\hline & $(2.57)$ & $(5.83)$ & (4.49) & (18.68) & $(4.96)$ & (7.10) & (4.33) & (4.18) & (12.93) \\
\hline \multirow[t]{2}{*}{ DL_NETFDI } & $-0.457 * * *$ & 0.480 & $0.667^{12 \%}$ & 1.162 & 0.252 & 0.056 & 0.040 & $0.454^{*}$ & 0.199 \\
\hline & $(0.09)$ & $(0.38)$ & $(0.43)$ & (1.14) & $(0.43)$ & $(0.06)$ & $(0.11)$ & $(0.27)$ & $(0.21)$ \\
\hline \multirow[t]{2}{*}{ lag(CAB_GDP, 2) } & $0.256^{* * *}$ & -0.655 & $-0.473 * *$ & -0.318 & 0.580 & 1.095 & $\begin{array}{l}1.520 \\
* * *\end{array}$ & 0.177 & -0.069 \\
\hline & $(0.06)$ & $(0.52)$ & $(0.23)$ & $(0.37)$ & $(0.45)$ & $(0.91)$ & $(0.29)$ & $(0.12)$ & $(0.48)$ \\
\hline \multirow[t]{2}{*}{ EX_DIV } & $1.427 *$ & $-\overline{15005^{11 \%}}$ & $23.351 * * *$ & -4.152 & 12.842 & 1.785 & $10.197^{11 \%}$ & -10.853 & -10.421 \\
\hline & $(0.85)$ & $(9.59)$ & $(8.09)$ & $(4.60)$ & (13.38) & (9.55) & (6.44) & $(15.82)$ & (21.74) \\
\hline \multirow[t]{2}{*}{ DL_NFA } & 0.152 & -0.265 & -1.448 & 1.832 & 2.370 & 0.126 & $0.934 * * *$ & 0.598 & -0.099 \\
\hline & $(0.19)$ & $(0.23)$ & (3.86) & $(6.96)$ & (5.93) & $(0.27)$ & $(0.24)$ & $(0.59)$ & $(0.71)$ \\
\hline \multirow{2}{*}{$\begin{array}{l}\text { lag(DL_RESERVE_Y, } \\
\text { 0) }\end{array}$} & 0.392 & $-4.759^{*}$ & 5.889 & 4.694 & -2.730 & 6.548 & $11.331 * *$ & -1.586 & 2.781 \\
\hline & (1.69) & $(2.85)$ & $(4.42)$ & $(7.60)$ & (5.38) & (4.46) & (4.92) & (4.35) & (7.58) \\
\hline \multirow[t]{2}{*}{ Constant } & & -0.396 & $-4.145 * *$ & $-3.089 *$ & $-4.119 * *$ & 0.121 & $-10.006^{*}$ & -1.362 & -0.003 \\
\hline & & (1.70) & (1.65) & (1.73) & (1.76) & (1.12) & (5.42) & (2.75) & (1.67) \\
\hline $\mathbf{R}$ squared & & 0.598 & 0.802 & 0.865 & 0.636 & 0.678 & 0.925 & 0.847 & 0.677 \\
\hline Adjusted R squared & & 0.236 & 0.623 & 0.744 & 0.309 & 0.389 & 0.857 & 0.710 & 0.386 \\
\hline
\end{tabular}

where $\Gamma_{i}=-\left(1-\lambda_{i}\right), \quad \rho_{0}=\mu_{i} /\left(-\Gamma_{i}\right), \quad \rho_{p}=\left(\theta_{p 0 i}+\theta_{p l i}\right) /\left(-\Gamma_{i}\right)$

Table II: PMG Estimates (Pesaran et al. 1999) 
The long run common coefficients are captured by $\rho_{p}$ and $\rho_{0}$, while the error correction coefficients $\Gamma_{\mathrm{i}}$ and the short run coefficients $\theta_{\mathrm{pli}}$ are country specific. We use a program written in R by Piotr Zientara and Lech Kujawski using "back-substitution" algorithm mentioned in Pesaran et al. (1999). Convergence is achieved after 23 iterations.

The results are reported in Table II above. Post estimation diagnostics indicate residuals are robust to both heteroscedasticity and autocorrelation.

\section{Error correction coefficients}

The adjustment towards the long run can be seen in the error correction coefficients $\left(\Gamma_{\mathrm{i}}\right)$. A negative error correction term indicates dynamic stability and that the long run relationship exists (Ezeaku et al., 2019). $\Gamma_{\mathrm{i}}$ are found to be highly significant and negative in all the countries indicating a high degree of stability in the system.

\section{Long run relationship}

Neither AE monetary spillovers nor precautionary motive is significant in the long run. This reflects long run neutrality of money, as well as achievement of equilibrium in capital flows that makes precautionary motive redundant. However, mercantilist policy captured through current account-to-GDP ratio (CAB_GDP) and export diversification index (EX_DIV) is found to be significant. The current account ratio significantly undervalues RER by 0.26 percent and this is comparable to the FE estimates. The export diversification index, found to be insignificant in the FE estimates, now significantly undervalues the multilateral RER by 1.42 percent. Long run strategy of export diversification in these EMEs is captured through this effect. The significant long run under-valuation from mercantilist efforts of these EMEs justifies the evidence of long run appreciation commonly seen in AEs. Controls for country heterogeneity yield results comparable to the FE estimates.

\section{Short run relationship}

China, India, Mexico, Russia, Thailand and Turkey show negative impact of growth in assets holdings (DL_ASTS_US) on RER misalignment. However, AE monetary spillover is significant only in Mexico (5.7), India (-4.8) and China (-2.6). Mercantilist undervaluation is found to be present, only for China and Russia indicating their stronger export-orientation compared to other EMEs. However, contrary to expectations, mercantilist policy (CAB_GDP) has a negative effect ( -0.47 percent) on Chinese RER, and possibly captures a retaliatory effect.

The index of export diversification (EX_DIV) is significant for China and undervalues RER to the extent of 23.4 percent. This indicates that mercantilist motive in China to a great extent can be captured through diversification, rather than the usual current account surplus data. EX_DIV also under-values Russian 
RER (10.20 percent) but at 11 percent level of significance. Except in Russia and Brazil, reserves do not affect misalignment in the short-run. The precautionary policy is seen to be particularly active for Russia with both DL_NFA and DL_RESERVE_Y significant. For India, both mercantilist/precautionary policies are found to be insignificant, but overvaluation occurs from AE spillovers as well as fundamentals. To the best of the authors' knowledge such a PMG analysis in the present form is a new addition to the literature.

IV.3. Robustness checks

FE estimation: bilateral RER against US

Table III: FE Estimates (1998-2017) with Bilateral EME-US RER (HP filter based)

\begin{tabular}{|c|c|c|c|c|c|}
\hline & & & \multicolumn{3}{|c|}{ Dependent variable: } \\
\hline & & & & RER_DEV & \\
\hline & (IV.1A) & (IV.1B) & (IV.1C) & (IV.1D) & (IV.1E) \\
\hline DL_ASTS_US & $\begin{array}{l}-0.157 \\
(0.582)\end{array}$ & & & & \\
\hline DL_M2US & & $\begin{array}{l}-12.492 \\
(11.041)\end{array}$ & & & \\
\hline DL_WT_M2 & & & $\begin{array}{l}-4.841 * * \\
(2.180)\end{array}$ & & \\
\hline VIX_GM & & & & $\begin{array}{l}-0.019 \\
(0.025)\end{array}$ & \\
\hline DL_DEBTASTS_US & & & & & $\begin{array}{l}-0.260 \\
(0.423)\end{array}$ \\
\hline lag(REAL_G, 1) & $\begin{array}{l}-5.999 * * * \\
(1.793)\end{array}$ & $\begin{array}{l}-5.352 * * * \\
(1.511)\end{array}$ & $\begin{array}{l}-6.081 * * * \\
(1.549)\end{array}$ & $\begin{array}{l}-5.940 * * * \\
(1.817)\end{array}$ & $\begin{array}{l}-5.955^{* * *} \\
(1.827)\end{array}$ \\
\hline lag(DL_SOVDEBT_Y, 1) & $\begin{array}{l}0.845 \\
(1.752)\end{array}$ & $\begin{array}{l}0.650 \\
(1.783)\end{array}$ & $\begin{array}{l}0.737 \\
(1.534)\end{array}$ & $\begin{array}{l}1.051 \\
(1.908)\end{array}$ & $\begin{array}{l}0.869 \\
(1.793)\end{array}$ \\
\hline DL_NETFDI & $\begin{array}{l}0.034 \\
(0.048)\end{array}$ & $\begin{array}{l}0.030 \\
(0.050)\end{array}$ & $\begin{array}{l}0.027 \\
(0.041)\end{array}$ & $\begin{array}{l}0.035 \\
(0.052)\end{array}$ & $\begin{array}{l}0.035 \\
(0.049)\end{array}$ \\
\hline lag(CAB_GDP, 2) & $\begin{array}{l}0.158 * * * \\
(0.035)\end{array}$ & $\begin{array}{l}0.145 * * * \\
(0.037)\end{array}$ & $\begin{array}{l}0.174 * * * \\
(0.034)\end{array}$ & $\begin{array}{l}0.162 * * * \\
(0.023)\end{array}$ & $\begin{array}{l}0.155 * * * \\
(0.027)\end{array}$ \\
\hline EX_DIV & $\begin{array}{l}-0.062 \\
(0.944)\end{array}$ & $\begin{array}{l}-0.303 \\
(0.993)\end{array}$ & $\begin{array}{l}-0.139 \\
(0.917)\end{array}$ & $\begin{array}{l}-0.221 \\
(0.940)\end{array}$ & $\begin{array}{l}-0.072 \\
(0.914)\end{array}$ \\
\hline G_NFA & $\begin{array}{l}-0.037 \\
(0.080)\end{array}$ & $\begin{array}{l}-0.021 \\
(0.081)\end{array}$ & $\begin{array}{l}0.005 \\
(0.046)\end{array}$ & $\begin{array}{l}-0.041 \\
(0.081)\end{array}$ & $\begin{array}{l}-0.041 \\
(0.081)\end{array}$ \\
\hline lag(DL_RESERVE_Y, 0) & $\begin{array}{l}5.774 * * * \\
(1.358)\end{array}$ & $\begin{array}{l}5.789 * * * \\
(1.171)\end{array}$ & $\begin{array}{l}5.356 * * * \\
(1.183)\end{array}$ & $\begin{array}{l}5.695 * * * \\
(1.143)\end{array}$ & $\begin{array}{l}5.675 * * * \\
(1.179)\end{array}$ \\
\hline dum_ump & $\begin{array}{l}-1.599 * * * \\
(0.416)\end{array}$ & $\begin{array}{l}-1.874 * * * \\
(0.540)\end{array}$ & $\begin{array}{l}-1.709 * * * \\
(0.458)\end{array}$ & $\begin{array}{l}-1.566 * * * \\
(0.429)\end{array}$ & $\begin{array}{l}-1.582 * * * \\
(0.409)\end{array}$ \\
\hline DL_M2US:INT_DIFF_MMR & & $\begin{array}{l}0.195 * * \\
(0.099)\end{array}$ & & & \\
\hline DL_WT_M2:INT_DIFF_MMR & & & $\begin{array}{l}-0.209 \\
(0.154)\end{array}$ & & \\
\hline Observations & 168 & 168 & 168 & 168 & 168 \\
\hline Within R2 & 0.506 & 0.520 & 0.527 & 0.507 & 0.506 \\
\hline Adjusted R2 & 0.453 & 0.466 & 0.474 & 0.455 & 0.454 \\
\hline F Statistic & $\begin{array}{l}17.157 * * * \\
(\mathrm{df}=9 ; 151)\end{array}$ & $\begin{array}{l}16.258 * * * \\
(\mathrm{df}=10 ; 150)\end{array}$ & $\begin{array}{l}16.726 * * * \\
(\mathrm{df}=10 ; 150)\end{array}$ & $\begin{array}{l}17.254 * * * \\
(\mathrm{df}=9 ; 151)\end{array}$ & $\begin{array}{l}17.219 * * * \\
(\mathrm{df}=9 ; 151)\end{array}$ \\
\hline
\end{tabular}

We run the same set of regressions in IV.1 to check if the estimates are robust to a different estimate of misalignment i.e., misalignment in bilateral EME-US RER from trend-determined equilibrium. We use 
trends derived from Hodrick-Prescott (HP) (RER_DEV) and Hamilton filters (RER_DEVH). The results of five estimations for each measure (IV.1 $\mathrm{F}$ to $\mathrm{J}$ for RER_DEV, IV.1 $\mathrm{K}$ to $\mathrm{O}$ for RER_DEVH) are reported in Tables III and IV respectively. Inferences are made with cluster-robust HAC standard errors.

Table IV: FE Estimates (1998-2017) with Bilateral EME-US RER (Hamilton, 2018 filter based)

\begin{tabular}{|c|c|c|c|c|c|}
\hline & & & \multicolumn{3}{|c|}{ Dependent variable: } \\
\hline & & & \multicolumn{3}{|c|}{ RER_DEVH } \\
\hline & (IV.6K) & (IV.6L) & (IV.6M) & (IV.6N) & (IV.6O) \\
\hline DL_ASTS_US & $\begin{array}{l}-0.707 \\
(0.574)\end{array}$ & & & & \\
\hline DL_M2US & & $\begin{array}{l}-3.343 \\
(9.276)\end{array}$ & & & \\
\hline DL_WT_M2 & & & $\begin{array}{l}-7.662 * \\
(4.266)\end{array}$ & & \\
\hline VIX_GM & & & & $\begin{array}{l}0.039^{13 \%} \\
(0.026)\end{array}$ & \\
\hline DL_DEBTASTS_US & & & & & $\begin{array}{l}-0.769 * * \\
(0.347)\end{array}$ \\
\hline lag(REAL_G, 1) & $\begin{array}{l}-8.914 * * * \\
(0.940)\end{array}$ & $\begin{array}{l}-9.096 * * * \\
(0.848)\end{array}$ & $\begin{array}{l}-8.718 * * * \\
(0.766)\end{array}$ & $\begin{array}{l}-8.596 * * * \\
(1.103)\end{array}$ & $\begin{array}{l}-8.680 * * * \\
(0.957)\end{array}$ \\
\hline lag(DL_SOVDEBT_Y, 1) & $\begin{array}{l}1.741 \\
(1.618)\end{array}$ & $\begin{array}{l}1.138 \\
(1.346)\end{array}$ & $\begin{array}{l}2.018 \\
(1.719)\end{array}$ & $\begin{array}{l}2.109 \\
(1.925)\end{array}$ & $\begin{array}{l}1.997 \\
(1.903)\end{array}$ \\
\hline DL_NETFDI & $\begin{array}{l}0.024 \\
(0.074)\end{array}$ & $\begin{array}{l}-0.003 \\
(0.062)\end{array}$ & $\begin{array}{l}0.026 \\
(0.079)\end{array}$ & $\begin{array}{l}0.031 \\
(0.076)\end{array}$ & $\begin{array}{l}0.029 \\
(0.079)\end{array}$ \\
\hline lag(CAB_GDP, 2) & $\begin{array}{l}-0.011 \\
(0.055)\end{array}$ & $\begin{array}{l}-0.021 \\
(0.045)\end{array}$ & $\begin{array}{l}-0.005 \\
(0.038)\end{array}$ & $\begin{array}{l}-0.032 \\
(0.043)\end{array}$ & $\begin{array}{l}-0.023 \\
(0.048)\end{array}$ \\
\hline EX_DIV & $\begin{array}{l}-1.960 * * \\
(0.968)\end{array}$ & $\begin{array}{l}-1.695^{*} \\
(1.008)\end{array}$ & $\begin{array}{l}-2.082 * * \\
(0.932)\end{array}$ & $\begin{array}{l}-1.772^{* *} \\
(0.867)\end{array}$ & $\begin{array}{l}-2.023 * * \\
(0.966)\end{array}$ \\
\hline G_NFA & $\begin{array}{l}-0.049 \\
(0.107)\end{array}$ & $\begin{array}{l}-0.080 \\
(0.136)\end{array}$ & $\begin{array}{l}-0.028 \\
(0.104)\end{array}$ & $\begin{array}{l}-0.057 \\
(0.114)\end{array}$ & $\begin{array}{l}-0.064 \\
(0.106)\end{array}$ \\
\hline lag(DL_RESERVE_Y,0) & $\begin{array}{l}7.007 * * * \\
(1.111)\end{array}$ & $\begin{array}{l}6.336 * * * \\
(1.030)\end{array}$ & $\begin{array}{l}6.365 * * * \\
(1.136)\end{array}$ & $\begin{array}{l}6.388 * * * \\
(0.926)\end{array}$ & $\begin{array}{l}6.531 * * * \\
(0.968)\end{array}$ \\
\hline dum_ump & $\begin{array}{l}-0.880^{* *} \\
(0.449)\end{array}$ & $\begin{array}{l}-0.675^{*} \\
(0.391)\end{array}$ & $\begin{array}{l}-1.036^{* *} \\
(0.474)\end{array}$ & $\begin{array}{l}-1.098 * * \\
(0.465)\end{array}$ & $\begin{array}{l}-0.864 * * \\
(0.421)\end{array}$ \\
\hline DL_M2US:INT_DIFF_MMR & & $\begin{array}{l}0.843 * * * \\
(0.188)\end{array}$ & & & \\
\hline DL_WT_M2:INT_DIFF_MMR & & & $\begin{array}{l}0.080 \\
(0.227)\end{array}$ & & \\
\hline Observations & 168 & 168 & 168 & 168 & 168 \\
\hline $\mathrm{R} 2$ & 0.617 & 0.671 & 0.626 & 0.615 & 0.618 \\
\hline Adjusted R2 & 0.576 & 0.634 & 0.583 & 0.575 & 0.578 \\
\hline F Statistic & $\begin{array}{l}26.986 * * * \\
(\mathrm{df}=9 ; 151)\end{array}$ & $\begin{array}{l}30.596 * * * \\
(\mathrm{df}=10 ; 150)\end{array}$ & $\begin{array}{l}25.077 * * * \\
(\mathrm{df}=10 ; 150)\end{array}$ & $\begin{array}{l}26.843 * * * \\
(\mathrm{df}=9 ; 151)\end{array}$ & $\begin{array}{l}27.163 * * * \\
(\mathrm{df}=9 ; 151)\end{array}$ \\
\hline
\end{tabular}

Hypothesized overvaluation from AE monetary policy is sustained here only with weighted money supply of AEs e.g. DL_WT_M2 (4.8 percent for RER_DEV and 7.1 percent for RER_DEVH) showing that the liquidity channel is more important for the bilateral EME-US RER. An increase in relative overall liquidity in AEs puts an upward pressure on EME prices, in general. A marginal and significant overvaluation of 0.8 percent is seen from US debt asset holdings in EMEs with RER_DEVH (Table IV). This shows that the risky component of portfolio rebalancing is more important for the bilateral EME-US RER. It is insignificant with multilateral RER. The interactive effect between monetary variable and 
interest differential is sustained with DL_M2US, the unweighted broad money in US. This is plausible given that our dependent variable is now the bilateral RER misalignment.

Precautionary reserves (DL_RESERVE_Y) emerge as a key factor with bilateral EME-US RER with a major and highly significant undervaluation across the models. Undervaluation from reserves lies in the range of around 6 (RER_DEV) to 7 (RER_DEVH) percent. This shows that EMEs are more likely to intervene against the US Dollar than other AEs, indicating the greater role of US in spillovers in comparison to other AEs. This is possibly due to Dollar benchmarking as well as due to higher capital flows from US.

The coefficient of DUM_UMP shows that in the UMP years, the earlier overall undervaluation with respect to US, UK and Japan is changed to overvaluation with respect to US. This impact (-0.8 to -1.7 percent) is highly significant. This again shows that US contributes significantly more to spillovers to EME RER.

"Pull" factors like real and sovereign debt ratio growth, which influence the assessment of EME fundamentals and vulnerabilities by AE investors, are found to significantly influence the bilateral RER. Real GDP growth retains its overvaluation impact at a high level of significance and in quantitative terms it is higher by 2 percent than the estimates of Table I.

Export diversification mimics the role of a fundamental as it overvalues RER by around 2 percent and at a high level of significance (Table IV). We believe this indicates that when EME diversifies its exports its reliance on bilateral trade with US is reduced and hence considerably reduces the undervaluation in the bilateral RER originating from mercantilist motive. Again, positive coefficient estimates of EX_DIV with multilateral RER (Table I) reinforces that export diversification increases the mercantilist motive when transacting with other AEs, although it is not statistically significant.

\section{CCE estimation}

The models in IV.1 were checked for cross sectional dependence (CD) because large open economies might be under the influence of several common factors not addressed through the covariates, especially since the cross-sectional dimension $(\mathrm{N})$ is not large. All the models estimated with multilateral RER in specification IV.1. A to E (Table I) and those with RER_DEVH in specification IV.1 K to O (Table IV) rejected $\mathrm{CD}^{32}$ (Appendix Table A5). However, models IV.1 $\mathrm{F}$ to $\mathrm{J}$ with bilateral EME-US RER deviations from HP trend (RER_DEV) show significant CD meaning efficiency loss of parameter estimates. Post-

\footnotetext{
${ }^{32}$ We check the Pesaran (2004) tau statistic, the BPLM (Breusch and Pagan, 1980) statistic as well as bias-corrected scaled LM statistic (Baltagi et al., 2012) which is a better version of the BPLM test. These tests use the pair-wise correlations between residuals estimated from separate cross-sectional OLS regressions to build the LM statistic.
} 
estimation diagnostics like Durbin-Watson test for serial correlation and Breusch-Pagan test for heteroscedasticity indicate that the residuals from the benchmark regression with multilateral RER (MSALIGN_MULT) and RER_DEVH are robust, along with cross-independence. But the estimates with bilateral RER_DEV are not robust to autocorrelation. Although cluster-robust HAC standard errors ensure consistent inferences in presence of heteroscedasticity or autocorrelation, the problem of crossdependence is not accounted for. Hence, we re-estimate IV.1 F to J with RER_DEV using the CCE estimator and results are reported in Table V. The CCE residuals satisfy robustness to these issues.

Since averages of dummy variable as well as the interactive term have no economic meaning, these were dropped from the regression. The dummy variable for UMP period additionally may be reflecting a part of the common correlated effects and hence cannot be included to avoid double counting. The specifications with AE monetary variables DL_M2_US and VIX_GM could not be replicated here, because the augmented equation can only be estimated if there is variation in the regressors across the cross-sectional units. We do not incorporate any trend in the model and compute robust 'White' standard errors.

Interestingly, the portfolio rebalancing effect (DL_ASTS_US), which was absent with fixed effects estimation with bilateral RER previously (models IV.1 F to J), is significant in the CCE estimation. This shows that spillovers through portfolio rebalancing is robust across trade-weighted multilateral and bilateral RERs. This follows from the micro-founded model in Alpanda and Kabaca (2020) which shows that $\mathrm{AE}$ money growth can flow into developing countries due to portfolio rebalancing. The overvaluation impact is found to be almost same at 1.7 percent.

Real GDP growth retains its significance across the models. We see that in comparison to the other FE estimations IV.1, the growth in sovereign debt ratio does not mimic fundamentals, but undervalues RER reflecting vulnerability.

The CAB-GDP ratio is significant only with weighted broad money growth, showing a small although significant amount of undervaluation (around 0.25 percent consistent with model IV.1). The negative impact of export diversification is retained here in all the models with a high level of significance. This reiterates that export diversification reduces the EME mercantilist motive against US. We find a positive impact of reserves on RER_DEV with DL_ASTS_US as the monetary variable. This effect is found to be significant too and the magnitude is comparable to the estimated coefficient in IV.1 A. 
Table V: CCE (Pesaran 2006) Estimates with Bilateral EME-US RER_DEV (HP filter based)

\begin{tabular}{|c|c|c|c|}
\hline & \multicolumn{3}{|c|}{ Dependent variable: } \\
\hline & & ER_DEV & \\
\hline & (IV.6A) & $(\mathrm{IV} .6 \mathrm{C})$ & $(\mathrm{IV} .6 \mathrm{E})$ \\
\hline DL_ASTS_US & $\begin{array}{l}-1.713^{* *} \\
(0.904)\end{array}$ & & \\
\hline DL_WT_M2 & & $\begin{array}{l}-22.078 \\
(16.341)\end{array}$ & \\
\hline DL_DEBTASTS_US & & & $\begin{array}{l}0.847 \\
(0.566)\end{array}$ \\
\hline lag(REAL_G, 1) & $\begin{array}{l}-5.684 * * \\
(2.486)\end{array}$ & $\begin{array}{l}-6.270 * * \\
(2.554)\end{array}$ & $\begin{array}{l}-8.368 * * \\
(3.481)\end{array}$ \\
\hline lag(DL_SOVDEBT_Y,1) & $\begin{array}{l}1.569 \\
(2.106)\end{array}$ & $\begin{array}{l}4.900 * * \\
(2.493)\end{array}$ & $\begin{array}{l}4.788 * * * \\
(1.693)\end{array}$ \\
\hline DL_NETFDI & $\begin{array}{l}0.098 \\
(0.159)\end{array}$ & $\begin{array}{l}0.266 * * * \\
(0.094\end{array}$ & $\begin{array}{l}-0.012 \\
(0.128)\end{array}$ \\
\hline lag(CAB_GDP, 2) & $\begin{array}{l}0.169 \\
(0.190)\end{array}$ & $\begin{array}{l}0.252 * * \\
(0.110)\end{array}$ & $\begin{array}{l}0.203 \\
(0.142)\end{array}$ \\
\hline EX_DIV & $\begin{array}{l}-3.888^{* *} \\
(2.020)\end{array}$ & $\begin{array}{l}-6.350 * * \\
(3.074)\end{array}$ & $\begin{array}{l}-4.806^{* *} \\
(2.435)\end{array}$ \\
\hline DL_NFA & $\begin{array}{l}0.875 \\
(1.245)\end{array}$ & $\begin{array}{l}-0.559 \\
(0.886)\end{array}$ & $\begin{array}{l}0.770^{12 \%} \\
(0.501)\end{array}$ \\
\hline lag(DL_RESERVE_Y,0) & $\begin{array}{l}3.161 * * \\
(1.548)\end{array}$ & $\begin{array}{l}2.703 * * \\
(1.357)\end{array}$ & $\begin{array}{l}1.198 \\
(2.646)\end{array}$ \\
\hline y.bar & $\begin{array}{l}0.942 * * * \\
(0.116)\end{array}$ & $\begin{array}{l}1.041 * * * \\
(0.257)\end{array}$ & $\begin{array}{l}0.955 * * * \\
(0.266)\end{array}$ \\
\hline DL_ASTS_US.bar & $\begin{array}{l}1.358 \\
(0.927)\end{array}$ & & \\
\hline DL_WT_M2.bar & & & $\begin{array}{l}26.271 * * \\
(11.452)\end{array}$ \\
\hline DL_DEBTASTS_US.bar & & & $\begin{array}{l}0.500 \\
(2.060)\end{array}$ \\
\hline lag(REAL_G, 1).bar & $\begin{array}{l}3.637 * * * \\
(1.363)\end{array}$ & $\begin{array}{l}9.491 * \\
(5.253)\end{array}$ & $\begin{array}{l}8.340 * * \\
(3.345)\end{array}$ \\
\hline lag(DL_SOVDEBT_Y, 1).bar & $\begin{array}{l}0.352 \\
(3.110)\end{array}$ & $\begin{array}{l}-1.001 \\
(6.661)\end{array}$ & $\begin{array}{l}0.303 \\
(4.374)\end{array}$ \\
\hline DL_NETFDI.bar & $\begin{array}{l}0.034 \\
(0.053)\end{array}$ & $\begin{array}{l}0.129 \\
(0.139)\end{array}$ & $\begin{array}{l}0.110 \\
(0.151)\end{array}$ \\
\hline lag(CAB_GDP, 2).bar & $\begin{array}{l}0.021 \\
(0.122)\end{array}$ & $\begin{array}{l}-0.285^{* *} \\
(0.120)\end{array}$ & $\begin{array}{l}-0.047 \\
(0.120)\end{array}$ \\
\hline EX_DIV.bar & $\begin{array}{l}4.847 \\
(6.804)\end{array}$ & $\begin{array}{l}11.987 \\
(8.031)\end{array}$ & $\begin{array}{l}-0.232 \\
(2.311)\end{array}$ \\
\hline DL_NFA.bar & $\begin{array}{l}0.134 \\
(0.344)\end{array}$ & $\begin{array}{l}0.676 \\
(0.577)\end{array}$ & $\begin{array}{l}0.423 \\
(0.432)\end{array}$ \\
\hline lag(DL_RESERVE_Y, 0).bar & $\begin{array}{l}-1.231 \\
(3.644)\end{array}$ & $\begin{array}{l}-0.467 \\
(3.492)\end{array}$ & $\begin{array}{l}-3.408 \\
(4.035)\end{array}$ \\
\hline Constant & $\begin{array}{l}-1.904 \\
(12.440)\end{array}$ & $\begin{array}{l}-12.712 \\
(14.149)\end{array}$ & $\begin{array}{l}11.690 * * \\
(5.760)\end{array}$ \\
\hline Observations & 168 & 168 & 168 \\
\hline R2 & 0.789 & 0.797 & 0.861 \\
\hline
\end{tabular}




\section{A comparative analysis}

Over 1998-2017, "temporary pull” factors like mercantilist/precautionary policies undervalue RER. However, "permanent pull" factors like country fundamentals as well as "push" factor in AE monetary policy overvalue RER.

Around 2 percent RER overvaluation for every percentage growth in US assets holdings in an EME shows the importance of the portfolio rebalancing channel in $\mathrm{AE}$ monetary spillover for both misalignments in trade-weighted multilateral RER and bilateral EME-US RER. The liquidity channel too is found to significantly over-value bilateral EME-US RER. Overvaluation from country-specific factors is, however, much higher when compared to foreign monetary policy spillovers.

EME mercantilist motive is found to be more prominent with the trade-weighted multilateral RER, while precautionary motive is more functional with bilateral RER against US. This indicates that EMEs face a higher share of hot money flows from the US leading to such differential policy actions between US and other AEs. We find that EME export diversification benefits US since it reduces the mercantilist motive in the trade with US. In relative terms, the composite impact of undervaluation from EME mercantilist and precautionary policies dominates AE monetary spillovers.

Real growth impacts are also close across the models. In working with bilateral RER, sovereign debt to GDP ratio leads to undervaluation. This is in contrast to the estimates with multilateral RER where this ratio led to overvaluation acting like a fundamental. This change in sovereign-debt-RER dynamics with respect to US and other AEs needs further exploration. Possibly this implies that sovereign debt captures the effect of crowding out of private borrowings in the case of multilateral RER, while for bilateral RER it is more a proxy for country vulnerability.

From the short run PMG estimates, export diversification is seen to be especially active for Chinese multilateral RER, showing its outward oriented growth strategy. Russia shows presence of both mercantilist and precautionary under-valuation. India, however, shows absence of either mercantilist or precautionary undervaluation in multilateral RER.

The fixed effects are reported in Appendix Table A6. Negative (positive) FE for the multilateral (bilateral) RER show that the EMEs are, in general, overvalued (undervalued) with respect to the basket of AEs (US). The strength of the US dollar as an international currency may be leading to such a difference.

\section{Conclusions}


The study provides some interesting policy implications for EMEs as well as AEs. We find, on the average over 1998-2017, conventional AE monetary policy has significantly overvalued EME RER providing evidence that $\mathrm{AE}$ monetary expansion has the potential to push up EME prices and rebalance EME current account. Hence, monetary spillovers need more exploration in the debate on global rebalancing. In the UMP years, multilateral EME RER against a broader set of AEs saw significant undervaluation, while bilateral EME-US RER has seen overvaluation. This indicates the greater role of US in spillovers in comparison to other AEs. EME precautionary policy is active only in the case of bilateral EME US RER, which again underlines the US spillover driven volatility. The impact of EME precautionary reserve policy can be detrimental towards the RER of AEs, especially US. This finding has implications for future policy cooperation between EMEs and AEs. More international liquidity support can mitigate this effect.

That spillovers from US were significantly more in the UMP years, shows that extreme events in US can create significant negative externalities in EMEs and pass on a part of adjustment costs. Earlier studies, like Tiwari et al. (2020), show spillovers between asset classes can reduce the benefits of portfolio diversification. Similarly, we find monetary spillovers can transfer some costs to EMEs in a highly integrated financial system and affect their growth prospects reducing the scope of risk diversification.

We find the portfolio rebalancing channel of transmission to be prominent, as found in most earlier studies. Nevertheless, we provide new evidence that this effect can misalign RER in EMEs. It may be useful for EME monetary authorities to monitor portfolio inflows for future trends in RER, especially debt investment from US. The weighted measure of broad money in AEs is also significant, its overvaluation impact being considerably higher. This could be reflecting the umbrella effect from increased AE liquidity. The consistent overvaluation from fundamentals like real growth or FDI, even after accounting for both foreign and domestic policy impacts, shows that stronger EMEs are more likely to face the storm than EMEs that have weaker fundamentals. Weak EMEs with higher interest differentials see a part of their spillovers offset.

Our PMG estimates show that although the AE monetary impact and precautionary policy is absent in the long run, mercantilist policy is present in the long run which means that mercantilism in EMEs is not temporary, or scenario driven, but more a permanent strategy. This empirical study provides a basis for future research into the dynamics of adjustment of RER to foreign monetary policy. Although this analysis cannot make evidence-based conclusions on which of AEs or EMEs have played the role of leader/follower in the spillovers debate, it would be an interesting area of future research. But the domestic focus of $\mathrm{AE}$ monetary policy makes it unlikely they were the leaders. 
More research is also required on our finding that EME export diversification has reduced mercantilist undervaluation with respect to US. This can be interpreted as a desire of EMEs to substitute trade with US by other AEs. Future research could see how sovereign debt (high debt levels as in Aizenmann et al., 2014) can lead to overvaluation acting like a fundamental. More disaggregated debt data can be used. Another interesting study would be to understand how interest rate differential affects the risk of spillovers. While higher interest rate differential should lead to higher capital inflows, it may be covering higher risk premium for EMEs. This can be studied using higher frequency data e.g. VAR modelling that allows us to see how the impact of interest rate differential on RER changes over time in response to QE policy measures.

\section{References}

Ahmed, S. and Zlate, A. (2014), "Capital flows to emerging market economies: A brave new world?", Journal of International Money and Finance, 48, pp. 221-248.

http://dx.doi.org/10.1016/j.jimonfin.2014.05.015.

Aizenman, J., Binici, M. and Hutchison, M. M. (2014), "The transmission of federal reserve tapering news to emerging financial markets", NBER Working Paper Series No. 19980.

http://www.nber.org/papers/w19980

Aizenman, J. and Lee, J. (2005), "International reserves: Precautionary vs. mercantilist views, theory, and evidence”, IMF Working Papers, 05(198), p.1. http://dx.doi.org/10.5089/9781451862171.001.

Alpanda, S. and Kabaca, S. (2020), "International spillovers of large-scale asset purchases", Journal of the European Economic Association, 18(1), pp. 342-391. https://doi.org/10.1093/jeea/jvy053

Angelovska-Bezhoska, A., Mitreska, A. and Bojcheva-Terzijan, S. (2018), "The impact of the ECB's quantitative easing policy on capital flows in the CESEE region", Journal of Central Banking Theory and Practice, 7(2), pp. 25-48. http://dx.doi.org/10.2478/jcbtp-2018-0011.

Arellano, M. (1987), "Computing robust standard errors for within-groups estimators", Oxford Bulletin of Economics and Statistics, 49(4), pp. 431-434. https://doi.org/10.1111/j.1468-0084.1987.mp49004006.x

Anaya, P., Hachula, M. and Offermanns, C.J. (2017), "Spillovers of U.S. unconventional monetary policy to emerging markets: The role of capital flows", Journal of International Money and Finance, 73, pp. 275-295. http://dx.doi.org/10.1016/j.jimonfin.2017.02.008.

Baltagi, B., Feng, Q., and Kao, C. (2012), "A Lagrange multiplier test for cross-sectional dependence in a fixed effects panel data model”, Centre for Policy Research. 193. https://surface.syr.edu/cpr/193

Self-citation (blinded for Double-blind peer review). This is displayed in un-blinded paper.

Bernanke, B. (2005), "The global saving glut and the U.S. current account deficit”, Lecture delivered at Sandridge, Virginia Association of Economists, Richmond, Virginia.

Bertrand, M., Duflo, E. and Mullainathan, S. (2004), "How much should we trust differences-indifferences estimates?", The Quarterly Journal of Economics, 119(1), pp. 249-275.

http://dx.doi.org/10.1162/003355304772839588. 
Bowman, D., Londonoz, J. M., and Sapriza, H. (2014), “U.S. unconventional monetary policy and transmission to emerging market economies", International Finance Discussion Paper, 1109, pp. 1-42. http://dx.doi.org/10.17016/ifdp.2014.1109.

Breusch, T., and Pagan, A. (1980), "The Lagrange multiplier test and its applications to model specification in econometrics”, Review of Economic Studies, 47, pp. 239-253.

Cecchetti, S.G. and Disyatat, P. (2010), "Central Bank Tools and Liquidity Shortages”, FRBNY Economic Policy Review.

Cerutti, E., Claessens, S. and Puy, D. (2019), "Push factors and capital flows to emerging markets: why knowing your lender matters more than fundamentals", Journal of International Economics, 119, pp. 133149. http://dx.doi.org/10.1016/j.jinteco.2019.04.006.

Çekin, S. E., Hkiri, B., Tiwari, A.K., and Gupta, R. (2020), "The relationship between monetary policy and uncertainty in advanced economies: Evidence from time- and frequency-domains", The Quarterly Review of Economics and Finance, ISSN 1062-9769, https://doi.org/10.1016/j.qref.2020.05.010.

Chen, J., Mancini-Griffoli, T. and Sahay, R. (2014), "Spillovers from US monetary policy on emerging markets: Different this time?", IMF Working Papers, 14(240), p. 1.

http://dx.doi.org/10.5089/9781498380423.001.

Chinn, M.D., Eichengreen, B. and Ito, H. (2013), “A forensic analysis of global imbalances”, Oxford Economic Papers, 66(2), pp.465-490. http://dx.doi.org/10.1093/oep/gpt027.

Chebbi, T. (2019), "On the effects of asset purchase programs on emerging stock markets", International Economic Journal, 33:3, pp. 408-430, DOI: 10.1080/10168737.2019.1636844.

Dedola, L., Rivolta, G. and Stracca, L. (2017), "If the Fed sneezes, who catches a cold?", Journal of International Economics, 108, pp. S23-S41. http://dx.doi.org/10.1016/j.jinteco.2017.01.002.

Fratzscher, M., Lo Duca, M., and Straub, R. (2016), "ECB unconventional monetary policy: Market impact and international spillovers", IMF Economic Review, 64(1), p. 36.

Gagnon, J. E., Raskin, M. D., Remache, J. A. and Sack, B. P. (2011), “The financial market effects of the Federal Reserve's large-scale asset purchases", International Journal of Central Banking 7(1), pp. 3-44.

March.

Georgiadis, G. (2016), “Determinants of global spillovers from US monetary policy”, Journal of International Money and Finance, 67, pp. 41-61.

Hamilton, J. (2017), "Why you should never use the Hodrick-Prescott filter", NBER Working Paper No. 23429 .

Helbling, T., Huidrom, R., Kose, M.A., and Otrok, C. (2011), "Do credit shocks matter? A global perspective", European Economic Review, 55(3), pp. 340-353.

http://dx.doi.org/10.1016/j.euroecorev.2010.12.009.

IMF (International Monetary Fund) (2013), "IMF Multilateral policy issues report: 2013 pilot external sector report", IMF Policy Paper. https://www.imf.org/external/np/pp/eng/2013/062013.pdf

Kucharčuková, O. B., Claeys, P. and Vašíček, B. (2016), "Spillover of the ECB's monetary policy outside the euro area: How different is conventional from unconventional policy?", Journal of Policy Modelling, 38(2), pp. 199-225. 
Levin, A., Lin, C.-F., and Chu, C-S. J. (2002), "Unit root tests in panel data: asymptotic and finite sample properties", Journal of Econometrics, Elsevier. 108(1), pp. 1-24.

Lim, J.J., Mohapatra, S. and Stocker, M. (2014), "Tinker, taper, QE, bye? The effect of quantitative easing on financial flows to developing countries", The World Bank, Development Prospects Group, Global Macroeconomics Unit, Policy Research Working Papers, 6820, p. 1.

http://dx.doi.org/10.1596/1813-9450-6820.

Lin, J-Y., Batmunkh M-U. J. , Moslehpour, M., Lin C-Y. and Lei, K-M. (2017), “Impact analysis of US quantitative easing policy on emerging markets", International Journal of Emerging Markets, 13(1), pp. $185-202$.

MacDonald, M. (2017), "International capital market frictions and spillovers from quantitative easing", Journal of International Money and Finance, 70, pp. 135-156.

http://dx.doi.org/10.1016/j.jimonfin.2016.08.003.

Mishra, P., Moriyama, K., N’Diaye, P. P. and Nguyen, L. (2014), "Impact of FED tapering announcements on emerging markets", IMF Working Papers, 14/109, p.1.

http://dx.doi.org/10.5089/9781498361484.001.

Moulton, B. R. (1990), "An illustration of a pitfall in estimating the effects of aggregate variables in micro units", Review of Economics and Statistics, 72(2), pp. 334-338.

Nayak, S. and Baig, M.A. (2019), "International reserves and domestic money market disequilibrium: Empirics for India and China", International Journal of Emerging Markets, Vol. 14 No. 5, pp. 1081-1101. https://doi.org/10.1108/IJOEM-10-2018-0536

Nier, E., Sedik, T. S., and Mondino, T. (2014), "Gross private capital flows to emerging markets: Can the global financial cycle be tamed?”, IMF Working Papers, 14/196, p.1.

http://dx.doi.org/10.5089/9781498351867.001.

Nickell, S. (1981), "Biases in dynamic models with fixed effects", Econometrica, 49(6), p.1417. http://dx.doi.org/10.2307/1911408.

Papadamou, S., Kyriazis, N.A. and Tzeremes, P.G. (2019), "Spillover effects of US QE and QE tapering on African and Middle Eastern stock indices", Journal of Risk and Financial Management, 12(2), pp. 57. http://dx.doi.org/10.3390/jrfm12020057.

Papadamou, S., Siriopoulos, C. and Kyriazis, N.A. (2020), "A survey of empirical findings on unconventional central bank policies", Journal of Economic Studies, Vol. ahead-of-print No. ahead-ofprint. https://doi.org/10.1108/JES-04-2019-0186.

Passari, E. and Rey, H. (2015), "Financial flows and the international monetary system", The Economic Journal, 125(584), pp .675-698. http://dx.doi.org/10.1111/ecoj.12268.

Pesaran, M. H. (2004), "General Diagnostic Tests for Cross Section Dependence in Panels." CESifo Working Paper Series, 1229.

Pesaran, M.H. (2006), "Estimation and inference in large heterogeneous panels with a multifactor error structure", Econometrica 74, pp. 967-1012.

Pesaran, M. H., Shin, Y. and Smith, R.P. (1999), "Pooled mean group estimation of dynamic heterogeneous panels", Journal of the American Statistical Association, 94(446), pp. 621-634. 
Petersen, M. A. (2009), "Estimating standard errors in finance panel data sets: Comparing approaches", Review of Financial Studies, 22(1), pp. 435-480. doi: 10.1093/rfs/hhn053.

Prabheesh, K.P., Malathy, D. and Madhumathi, R. (2009), "Precautionary and mercantilist approaches to demand for international reserves: an empirical investigation in the Indian context", Macroeconomics and Finance in Emerging Market Economies, 2(2), pp. 279-291.

http://dx.doi.org/10.1080/17520840902726367.

Rajan, R. (2015), “Competitive monetary easing: is it yesterday once more?”, Macroeconomics and Finance in Emerging Market Economies, 8(1-2), pp. 5-16. http://dx.doi.org/10.1080/17520843.2014.992451.

Rey, H. (2013), "Dilemma not trilemma: the global cycle and monetary policy independence", Lecture in Jackson Hole Symposium (Federal Reserve Bank of Kansas City), pp. 285-333.

https://www.kansascityfed.org/publicat/sympos/2013/2013Rey.pdf

Thompson, S.B. (2011), "Simple formulas for standard errors that cluster by both firm and time", Journal of Financial Economics, 99(1), pp. 1-10.

Tillmann, P. (2016), "Unconventional monetary policy and the spillovers to emerging markets", Journal of International Money and Finance, 66, pp. 136-156. http://dx.doi.org/10.1016/j.jimonfin.2015.12.010.

Tiwari, A.K., André, C. and Gupta, R. (2020), "Spillovers between US real estate and financial assets in time and frequency domains", Journal of Property Investment \& Finance, Vol. ahead-of-print No. aheadof-print. https://doi.org/10.1108/JPIF-08-2019-0110

Tiwari, A.K., Jana, R.K. and Roubaud, D. (2019), "The policy uncertainty and market volatility puzzle: Evidence from wavelet analysis", Finance Research Letters, Volume 31, https://doi.org/10.1016/j.frl.2018.11.016.

Triki, M.B. and Maktouf, S. (2015), "Purchasing power parity as a long-term memory process: Evidence from some emerging countries", International Journal of Emerging Markets, 10(4), pp. 711-725. https://doi.org/10.1108/JoEM-02-2012-0021

Wang, Y. (2012), "Seeking a balanced approach on the global economic rebalancing: China's answers to international policy cooperation", Oxford Review of Economic Policy, 28(3), pp. 569 - 586. https://doi.org/10.1093/oxrep/grs032.

Weale, M. and Wieladek, T. (2016), "What are the macroeconomic effects of asset purchases?", Journal of Monetary Economics, 79, pp. 81-93. http://dx.doi.org/10.1016/j.jmoneco.2016.03.010 . 


\section{Appendix}

Table A1. Variables, Sources and Panel Unit Root testing

\begin{tabular}{|c|c|c|c|c|}
\hline Variables & Data Sources & Unit Root & $\begin{array}{l}\text { Trans- } \\
\text { formation } \\
\text { taken }\end{array}$ & Unit Root \\
\hline \multicolumn{5}{|l|}{ AE Monetary Variables } \\
\hline Broad money US & WDI & Yes $(0.99)$ & Growth, DL_M2_US & No $(0.00)$ \\
\hline Weighted broad money US,UK, Japan & WDI & Yes $(0.99)$ & Growth, DL_WT_M2 & No $(0.00)$ \\
\hline Volatility index, VIX_GM & CBOE & No $(0.00)$ & None & \\
\hline $\begin{array}{l}\text { Portfolio assets holdings by US } \\
\text { investors }\end{array}$ & IMF CPIS & Yes $(0.99)$ & Growth, DL_ASTS_US & No $(0.00)$ \\
\hline $\begin{array}{l}\text { Portfolio debt assets holdings by US } \\
\text { investors }\end{array}$ & IMF CPIS & Yes (1) & Growth, DL_DEBTASTS_US & No $(0.00)$ \\
\hline \multicolumn{5}{|l|}{ Country-specific factors } \\
\hline $\begin{array}{l}\text { Real GDP (Current GDP in US Dollars } \\
\text { deflated to } 2010 \text { prices) }\end{array}$ & WDI & Yes (1.00) & Growth, REAL_G & No $(0.00)$ \\
\hline $\begin{array}{l}\text { Net Foreign direct investment (\% of } \\
\text { GDP) }\end{array}$ & WDI & No $(0.01)$ & Growth, DL_NETFDI* & No $(0.00)$ \\
\hline Government debt to GDP ratio & IMF IFS & Yes $(0.35)$ & Growth, DL_SOVDEBT_Y & No $(0.00)$ \\
\hline Consumer Price Index & WDI & Yes $(0.29)$ & Inflation, INF_CPI & No $(0.00)$ \\
\hline \multicolumn{5}{|l|}{ Domestic Policy } \\
\hline $\begin{array}{l}\text { Current a/c balance as \% of GDP, } \\
\text { CAB_GDP }\end{array}$ & WDI & No $(0.00)$ & None & \\
\hline Export diversification index, EX_DIV\# & $\begin{array}{l}\text { IMF Export } \\
\text { Diversification } \\
\text { database (1962- } \\
\text { 2014) }\end{array}$ & No $(0.01)$ & None & \\
\hline Total reserves ( $\%$ of GDP) & WDI & Yes $(0.12)$ & Growth, DL_RESERVE_Y & No $(0.00)$ \\
\hline Net Foreign Assets & WDI & Yes (1.00) & Growth, DL_NFA & No $(0.00)$ \\
\hline
\end{tabular}

Table A2. Summary Statistics: AE Monetary Variables

\begin{tabular}{rrrrrr}
\hline & DL_ASTS_US & DL_M2US & DL_WT_M2 & VIX_GM & DL_DEBTASTS_US \\
\hline Mean & 0.106 & 0.061 & 0.039 & 19.740 & 0.073 \\
Median & 0.080 & 0.060 & 0.046 & 19.526 & 0.089 \\
Maximum & 1.018 & 0.111 & 0.158 & 30.274 & 1.010 \\
Minimum & -1.190 & -0.028 & -0.192 & 11.012 & -0.866 \\
Std. Dev. & 0.350 & 0.028 & 0.055 & 5.572 & 0.340 \\
Observations & 176 & 176 & 176 & 176 & 176 \\
\hline
\end{tabular}


Table A3. Summary Statistics: EME Variables

\begin{tabular}{llllllll}
\hline & REAL_G & DL_SOVDEBT_Y & DL_NETFDI & CAB_GDP & EX_DIV & DL_NFA & DL_RESERVE_Y \\
\hline Mean & 0.070 & -0.007 & 0.364 & 0.674 & 2.262 & 0.294 & 0.043 \\
Median & 0.087 & -0.009 & -0.022 & -0.357 & 2.069 & 0.144 & 0.027 \\
Maximum & 0.383 & 0.979 & 34.895 & 17.474 & 3.929 & 12.181 & 1.130 \\
Minimum & -0.816 & -0.840 & -23.502 & -8.937 & 1.759 & -4.035 & -0.371 \\
Std. Dev. & 0.155 & 0.166 & 4.366 & 4.350 & 0.477 & 1.630 & 0.177 \\
Observations & 176 & 176 & 176 & 176 & 176 & 176 & 176 \\
\hline
\end{tabular}

Table A4. Diagnostics of the FE Modelling

\begin{tabular}{|c|c|c|c|c|c|}
\hline & DL_ASTS_US & DL_M2_US & DL_WT_M2 & VIX_GM & DL_DEBTASTS_US \\
\hline & Model IV.1 A & Model IV.1 B & $\begin{array}{l}\text { Model IV.1 } \\
\text { C }\end{array}$ & Model IV.1 D & Model IV.1 E \\
\hline $\begin{array}{l}\text { Breusch-Pagan LM } \\
\text { Statistic for OLS } \$ \\
\text { Breusch-Pagan LM }\end{array}$ & $7.031 * * *$ & $6.812 * * *$ & $6.874 * * *$ & $7.194 * * *$ & $7.120 * * *$ \\
\hline $\begin{array}{l}\text { Statistic for time } \\
\text { effects }\end{array}$ & $-2.034^{\wedge}$ & $-2.037^{\wedge}$ & $-1.826^{\wedge}$ & $-2.127^{\wedge}$ & $-1.931^{\wedge}$ \\
\hline
\end{tabular}

Table A5. Statistics of Cross-sectional Dependence Test

\begin{tabular}{|c|c|c|c|c|c|}
\hline & DL_ASTS_US & DL_M2_US & DL_WT_M2 & VIX_GM & DL_DEBTASTS_US \\
\hline $\begin{array}{l}\text { Y: Multilateral } \\
\text { RER }\end{array}$ & Model IV.1 A & Model IV.1 B & Model IV.1 C & Model IV.1 D & Model IV.1 E \\
\hline $\begin{array}{l}\text { Pesaran CD test ta } \\
\text { u statistic }\end{array}$ & $0.819^{\wedge}$ & $1.275^{\wedge}$ & $1.192^{\wedge}$ & $1.745^{\wedge}$ & $1.559^{\wedge}$ \\
\hline $\begin{array}{l}\text { Breusch-Pagan } \\
\text { LM test (1980) } \\
\text { Chi-square } \\
\text { statistic }\end{array}$ & $28.617^{\wedge}$ & $27.472^{\wedge}$ & $27.603^{\wedge}$ & $27.361^{\wedge}$ & $26.406^{\wedge}$ \\
\hline $\begin{array}{l}\text { Bias-corrected } \\
\text { Scaled LM test } \\
\text { (2012) tau statistic }\end{array}$ & $-0.140^{\wedge}$ & $-0.293^{\wedge}$ & $-0.275^{\wedge}$ & $-0.308^{\wedge}$ & $-0.435^{\wedge}$ \\
\hline Y:RER_DEV & Model IV.1 F & Model IV.1 G & Model IV.1 H & Model IV.1 I & Model IV.1 J \\
\hline $\begin{array}{l}\text { Pesaran CD test ta } \\
\text { u statistic }\end{array}$ & $4.697 * * *$ & $5.107 * * *$ & $3.905 * * *$ & $4.340 * * *$ & $4.390 * * *$ \\
\hline $\begin{array}{l}\text { Breusch-Pagan } \\
\text { LM test (1980) } \\
\text { Chi-square } \\
\text { statistic }\end{array}$ & $57.268 * * *$ & $63.239 * * *$ & $50.832 * * *$ & $58.241 * * *$ & $54.177 * * *$ \\
\hline $\begin{array}{l}\text { Bias-corrected } \\
\text { Scaled LM test } \\
\text { (2012) tau statistic }\end{array}$ & $3.711 * * *$ & $4.509 * * *$ & $2.851 * * *$ & $3.8412 * * *$ & $3.298 * * *$ \\
\hline Y: RER_DEVH & Model IV.1 K & Model IV.1 L & Model IV.1 M & Model IV.1 N & Model IV.1 O \\
\hline $\begin{array}{l}\text { Pesaran CD test ta } \\
\text { u statistic }\end{array}$ & $1.267^{\wedge}$ & $0.516^{\wedge}$ & $0.908^{\wedge}$ & $1.065^{\wedge}$ & $0.618^{\wedge}$ \\
\hline $\begin{array}{l}\text { Breusch-Pagan } \\
\text { LM test (1980) } \\
\text { Chi-square } \\
\text { statistic }\end{array}$ & $25.355^{\wedge}$ & $40.963^{*}$ & $27.341^{\wedge}$ & $26.961^{\wedge}$ & $26.781^{\wedge}$ \\
\hline $\begin{array}{l}\text { Bias-corrected } \\
\text { Scaled LM test } \\
\text { (2012) tau statistic }\end{array}$ & $-0.553^{\wedge}$ & $1.532^{\wedge}$ & $-0.288^{\wedge}$ & $-0.339^{\wedge}$ & $-0.363^{\wedge}$ \\
\hline
\end{tabular}


Table A6. Fixed Effects

\begin{tabular}{|c|c|c|c|c|c|c|c|c|}
\hline & Brazil & China & India & Indonesia & Mexico & Russia & Thailand & Turkey \\
\hline \multicolumn{9}{|c|}{ Models with Multilateral EME RER against US, UK and Japan (see Table I) } \\
\hline Model: IV.1A & -1.768 & -5.624 & -3.833 & -6.540 & -1.399 & -6.558 & -1.746 & -0.790 \\
\hline Model: IV.1B & -1.530 & -5.123 & -3.547 & -6.215 & -0.733 & -4.681 & -0.904 & -1.704 \\
\hline Model: IV.1C & -0.725 & -4.494 & -2.734 & -5.508 & 0.036 & -4.037 & -0.337 & -0.644 \\
\hline Model: IV.1D & -0.411 & -4.616 & -2.828 & -5.414 & 0.035 & -4.150 & -0.528 & 0.163 \\
\hline Model: IV.1E & -0.773 & -4.931 & -3.137 & -5.715 & -0.326 & -4.569 & -0.851 & -0.140 \\
\hline \multicolumn{9}{|c|}{ Models with Bilateral EME-US RER (HP filter based) (see Table III) } \\
\hline Model: IV.1F & 0.991 & 0.527 & 1.031 & 1.249 & 0.576 & -0.240 & 0.425 & 1.521 \\
\hline Model: IV.1G & 2.121 & 1.732 & 2.186 & 2.398 & 1.819 & 1.283 & 1.702 & 2.277 \\
\hline Model: IV.1H & 1.604 & 0.825 & 1.520 & 1.570 & 1.196 & 0.196 & 0.688 & 2.289 \\
\hline Model: IV.1I & 1.713 & 1.171 & 1.709 & 1.947 & 1.337 & 0.656 & 1.093 & 2.196 \\
\hline Model: IV.1J & 1.005 & 0.535 & 1.054 & 1.288 & 0.605 & -0.178 & 0.441 & 1.541 \\
\hline \multicolumn{9}{|c|}{ Models with Bilateral EME-US RER (Hamilton filter based) (see Table IV) } \\
\hline Model: IV.1K & 4.597 & 4.951 & 4.646 & 6.251 & 4.254 & 7.123 & 5.213 & 4.179 \\
\hline Model: IV.1L & 3.433 & 4.405 & 3.992 & 5.195 & 3.404 & 5.998 & 4.789 & 1.975 \\
\hline Model: IV.1M & 5.214 & 5.311 & 5.208 & 6.660 & 4.970 & 7.854 & 5.620 & 4.644 \\
\hline Model: IV.1N & 3.398 & 3.777 & 3.409 & 5.020 & 3.011 & 5.938 & 4.084 & 2.932 \\
\hline Model: IV.1O & 4.701 & 5.006 & 4.745 & 6.410 & 4.410 & 7.454 & 5.314 & 4.266 \\
\hline
\end{tabular}

